\title{
Differentiating between inherited and autocrystic zircon in granitoids
}

\author{
Hugo K.H. Olierook ${ }^{1,2 *}$, Christopher L. Kirkland ${ }^{1,2}$, Kristoffer Szilas ${ }^{3}$, Julie A. Hollis ${ }^{4}$, Nicholas \\ J. Gardiner ${ }^{5,6}$, Agnete Steenfelt ${ }^{7}$, Qiang Jiang ${ }^{1}$, Chris Yakymchuk ${ }^{8}$, Noreen J. Evans ${ }^{1,2}$, Bradley \\ J. McDonald ${ }^{1}$
}

${ }^{1}$ Centre for Exploration Targeting-Curtin Node, School of Earth and Planetary Sciences, Curtin University, GPO Box U1987, Perth, WA 6845, Australia

${ }^{2}$ John de Laeter Centre, Curtin University, GPO Box U1987, Perth, WA 6845, Australia

${ }^{3}$ Department of Geosciences and Natural Resource Management, University of Copenhagen, Øster Voldgade 10, 1350, Copenhagen, Denmark

${ }^{4}$ Department of Geology, Ministry of Mineral Resources, Government of Greenland, P.O. Box 930, 3900 Nuuk, Greenland

${ }^{5}$ School of Earth and Environmental Sciences, University of St. Andrews, St. Andrews KT16 9AL, United Kingdom

${ }^{6}$ School of Earth, Atmosphere and Environment, Monash University, Melbourne, Victoria 3800, Australia.

${ }^{7}$ The Geological Survey of Denmark and Greenland, Øster Voldgade 10, 1350 Copenhagen K, Denmark

${ }^{8}$ Department of Earth and Environmental Sciences, University of Waterloo, Waterloo, Ontario N2L 3G1,

Canada

*Corresponding author: hugo.olierook@curtin.edu.au; +61 892667827

(C) The Author(s) 2020. Published by Oxford University Press. All rights reserved. For Permissions, please e-mail: journals.permissions@oup.com 


\section{Abstract}

Inherited zircon, crystals that did not form in situ from their host magma but were incorporated from either the source region or assimilated from the wall-rock, is common but can be difficult to identify. Age, chemical and/or textural dissimilarity to the youngest zircon fraction are the primary mechanisms of distinguishing such grains. However, in $\mathrm{Zr}$-undersaturated magmas, the entire zircon population may be inherited and, if not identifiable via textural constraints, can lead to erroneous interpretation of magmatic crystallization age and magma source. Here, we present detailed field mapping of cross-cutting relationships, whole-rock geochemistry and zircon textural, $\mathrm{U}-\mathrm{Pb}$ and trace element data of trondhjemite, granodiorite and granite from two localities in a complex Archean gneiss terrane in southwest Greenland, which reveal cryptic zircon inheritance. Zircon textural, U-Pb and trace element data demonstrate that, in both localities, trondhjemite is the oldest rock ( $3011 \pm 5$ Ma, 2 $\sigma$ ), which is intruded by granodiorite (2978 $\pm 4 \mathrm{Ma}, 2 \sigma)$. However, granite intrusions, constrained by cross-cutting relationships as the youngest component, only contain inherited zircon derived from trondhjemite and granodiorite based on ages and trace element concentrations. Without age constraints on the older two lithologies, it would be tempting to consider the youngest zircon fraction as recording crystallization of the granite but this would be erroneous. Furthermore, wholerock geochemistry indicates that the granite contains only $6 \mu \mathrm{g} \mathrm{g}^{-1} \mathrm{Zr}$, extremely low for a granitoid with $\sim 77$ wt. $\% \mathrm{SiO}_{2}$. Such low $\mathrm{Zr}$ concentration explains the lack of autocrystic zircon in the granite. We expand on a differentiation tool that uses $\mathrm{Th} / \mathrm{U}$ ratios in zircon versus that in the whole rock to aid in the identification of inherited zircon. This work emphasizes the need for field observations, geochemistry, grain characterization, and precise geochronology to accurately determine igneous crystallization ages and differentiate between inherited and autocrystic zircon.

Keywords: Antecryst; autocryst; xenocryst; Akia Terrane; Archean; trace element 


\section{INTRODUCTION}

The mineral zircon $-\mathrm{ZrSiO}_{4}$ - is arguably the gold standard in geochronology (Harley \& Kelly, 2007, Krogh, 1973). Zircon is a ubiquitous trace mineral in felsic and, to a lesser extent, intermediate and mafic rocks and, very rarely, in ultramafic rocks (Corfu et al., 2003, Speer, 1980). Its success in geochronology stems from its physical and chemical properties, including its relative durability, hardness, chemical inertness, incorporation of trace amounts of $U$ and Th (Bea, 1996), negligible common- $\mathrm{Pb}$ content (Harley \& Kelly, 2007, Watson et al., 1997) and high closure temperature to $\mathrm{Pb}$ $\left(>900{ }^{\circ} \mathrm{C}\right.$; Cherniak \& Watson, 2001, Lee et al., 1997). Owing to the ability for zircon to survive crustal anatexis, particularly in dry systems (Harrison \& Watson, 1983, Villaros et al., 2009, Yakymchuk \& Brown, 2014), it can retain age and other isotopic information (e.g., Hf, O) in cores as well as commonly formed new zircon overgrowth rims. Although the survival of zircon in igneous systems is useful to understand the development of magmatic plumbing systems (Claiborne et al., 2010, Nasdala et al., 2014, Pack et al., 2016), its endurance can also be a hindrance, particularly when attempting to determine magma crystallization ages (Clarke, 2007, Roddick \& Bevier, 1995, Simon et al., 2008)

In igneous systems, which are supposed to have short-lived crystallization times $(<10 \mathrm{Myr}$, even for the most long-lived plutons and batholiths; Matzel et al., 2006, Miller et al., 2007), enigmatically older crystals of zircon are commonly encountered that are not related to an eruption or final pulse of magma crystallization (e.g., Broderick et al., 2015, Samperton et al., 2017, Wotzlaw et al., 2013). Miller et al. (2007) stated "it is no exaggeration to say that hundreds of zircon geochronologic studies have shown this to be true." By now, there are probably thousands of studies that have yielded zircon grains that are older than their magmatic crystallization age. These appreciably older crystals referred to as 'inherited' - can be a major obstacle in assigning a crystallization age to igneous rocks. Inherited zircon grains can themselves be subdivided into three basic categories (Fig. 1): (i) restitic zircon, originating from the source (Chappell et al., 1987, Eliasson \& Schöberg, 1991, Jeon \& 
Williams, 2018, Pidgeon \& Aftalion, 1978), (ii) xenocrystic zircon, incorporated into the melt via wall-rock assimilation and delivering foreign (i.e., xeno-) zircon into the magmatic plumbing system (Johnson, 1989, Kemp et al., 2005), and (iii) antecrystic zircon, grains formed in antecedence to the final crystallization phase but still part of the same magmatic plumbing system (Charlier et al., 2005, Smithies et al., 2015).

The identification of inherited zircon is most commonly made via age data (e.g., Siégel et al., 2018), aided by textural (e.g., Corfu et al., 2003), geochemical (e.g., Belousova et al., 2002, Kirkland et al., 2015) or other isotopic parameters (Liu et al., 2014, Siebel et al., 2009, Valley, 2003). Although age discrepancies are the most common technique, zircon antecrysts and occasionally xenocrysts may show negligible difference in age to the youngest fraction of zircon grains as a consequence of insufficient dating precision. In situations where there is negligible age difference, the presence of inherited zircon may be evidenced by resorbed grain cores with strong chemical differences to zircon overgrowths (Mundil et al., 2004, Siégel et al., 2018).

All the above scenarios assume that the youngest concordant fraction of zircon grains in a given igneous sample represents the crystallization phase of that melt. However, it has long been recognized that certain igneous rocks (e.g., ultramafic rocks, kimberlite; Hatch, 1908) can lack zircon that crystallized in the final stages of magma solidification - termed autocrysts (Miller et al., 2007). The tendency to crystallize zircon directly from the melt is a function of temperature, $\mathrm{Zr}$ concentrations in the melt, volatile content (especially $\mathrm{H}_{2} \mathrm{O}$ ) and bulk magma composition, with hotter, $\mathrm{Zr}$-depleted and drier melts less likely to develop zircon autocrysts and instead become dominated by xenocrystic or restitic zircon (Boehnke et al., 2013, Kirkland et al., 2015, Siégel et al., 2018, Watson \& Harrison, 1983, Watson \& Harrison, 2005). Although ultramafic and mafic magmas rarely crystallize zircon, a lack of auto- or antecrystic zircon grains may also occur in intermediate to felsic rocks. In the absence of textural evidence (e.g., resorbed cores) or chemical data (which may not be collected during routine 
$\mathrm{U}-\mathrm{Pb}$ analysis), is it possible to determine that the youngest zircon fraction is inherited (i.e., cryptic zircon inheritance)?

In this contribution, we present detailed field mapping, petrography, whole-rock geochemical data and zircon $\mathrm{U}-\mathrm{Pb}$, trace elements and textures of three igneous units from two proximal localities in the Mesoarchean Akia Terrane in southwest Greenland that bring this issue into focus. It is feasible that cryptic zircon inheritance is relatively common in the geological record and that, if undiagnosed, could lead to assignment of erroneously older crystallization ages to igneous rocks. Using petrography, zircon textures, zircon trace elements and whole-rock chemical data, we show that granitoid ages can be confidently assigned, which would have been impossible to address using U-Pb geochronology alone. We also describe a novel mechanism to differentiate autocrystic from inherited zircon grains via $\mathrm{Th} / \mathrm{U}$ ratios in zircon crystals versus whole-rock. Finally, we evaluate the causes and mechanisms of cryptic zircon inheritance in granitoids. Ultimately, we emphasize the importance of detailed geological mapping, sampling, whole-rock and zircon trace element analysis in conjunction with routinely-collected zircon textural and $\mathrm{U}-\mathrm{Pb}$ age data to aid in the identification of cryptic zircon inheritance.

\section{GEOLOGICAL SETTING OF THE AKIA TERRANE, SOUTHWEST GREENLAND}

The North Atlantic Craton in southern West Greenland contains an important crustal block that tracks crustal history from at least 3.8 to $2.5 \mathrm{Ga}$ (Fig. 2; Friend et al., 1988, Nutman \& Collerson, 1991). The craton extends west into Canada (Bridgwater \& Schiotte, 1991) and south-east into southeastern Greenland (Kalsbeek et al., 1993) and northwestern Scotland (Friend \& Kinny, 2001). The presently exposed surface of the North Atlantic Craton is dominated by felsic to intermediate orthogneisses intercalated with remnants of supracrustal belts and mafic to ultramafic and anorthositic plutonic 
rocks (see reviews of the North Atlantic Craton in West Greenland by Henriksen et al., 2009, Polat et al., 2015, Windley \& Garde, 2009).

The North Atlantic Craton in southwest Greenland comprises various terranes, of which the Akia Terrane (situated north of the capital city Nuuk) is a major constituent (Fig. 2). The Akia Terrane dominantly comprises rocks with crystallization ages that fall into two distinct age groupings, $\sim 3230$ $3190 \mathrm{Ma}$ and 3070-2970 Ma (Friend \& Nutman, 2005, Garde, 1997, Garde et al., 2000), with the latter being significantly more voluminous. Following major ca. 3050-2970 Ma diorite and tonalitetrondhjemite-granodiorite (TTG) magmatism and associated high-grade metamorphism, at least a portion of the supracrustal rocks in the Akia Terrane were deposited between 2877 and 2857 Ma onto the Mesoarchean basement (Kirkland et al., 2018a). These supracrustal rocks were subsequently buried to $>30 \mathrm{~km}$ depth, where they partially melted between 2857 and $2700 \mathrm{Ma}$. The timing and nature of this Neoarchean metamorphism along the edges of the Akia Terrane is consistent with similar conditions in surrounding terranes in West Greenland, implying a wide commonality of thermal conditions and linking of crustal elements at least by this time. Further greenschist to amphibolite-facies metamorphic events at c. $2630 \mathrm{Ma}$ and $2540 \mathrm{Ma}$ are recorded by metamorphic zircon overgrowths and neoblastic apatite (Kirkland et al., 2018b), and titanite (Kirkland et al., 2020), respectively.

\section{FIELD MAPPING AND SAMPLE SELECTION}

The present study was part of a structural, geochronological and geochemical investigation in the Maniitsoq region, southwestern Greenland, undertaken in 2016-2017 by the Ministry of Mineral Resources, Government of Greenland. Two localities (Table 1), situated within $30 \mathrm{~m}$ of each other, expose three generations of igneous rocks that are similarly affected by regional deformation (Fig. 3). 
In both localities, a regional, beige-coloured, coarse-grained porphyritic trondhjemite is intruded by up to $1 \mathrm{~m}$-wide grey, equigranular, medium-grained granodiorite dykes (Fig. 3a,b). In places, the trondhjemite has a moderately- developed foliation $\left(058 / 70^{\circ} \mathrm{S}\right)$ defined by mafic mineral layers, but this foliation is not always evident where mafic layers are lacking (Fig. 3).

In locality 1, a tabular granodiorite dyke cross-cuts the trondhjemite, almost perpendicular to the foliation in the trondhjemite (Fig. 3c). In locality 2, an irregular-shaped granodiorite body cross-cuts the trondhjemite host rock (Fig. 3b). The granodiorite is generally homogeneous and fine-grained, and does not display a noticeable fabric, other than larger scale open folding. However, the contacts between the granodiorite and the hosting trondhjemite commonly display protrusions of the former into the latter as small veinlets parallel to the foliation (e.g., Fig. 3d).

In locality 2 only, the granodiorite is cross-cut by a ptygmatically-folded, equigranular, very coarsegrained, K-feldspar rich granitic pegmatite with occasional thin granite veins into the granodiorite (Fig. 3b,d). The ptygmatically-folded granite also appears to enclose small enclaves of granodiorite (Fig. 3d) but the folded nature of the outcrop implies that the granodiorite is still connected in threedimensions (Fig. 3b).

Field mapping of localities 1 and 2 demonstrates that the relative chronology, from oldest to youngest, is trondhjemite, granodiorite dykes and (in locality 2 only) K-feldspar rich granite (Fig. 3). Three samples were selected from locality 1 , including two from relatively undeformed trondhjemite (871, 873 ) and one from the cross-cutting granodiorite (872), the latter being equivalent to sample 524254 in Scherstén and Garde (2013). Three samples were selected from locality 2, one each from the trondhjemite (1415), granodiorite (1417) and K-feldspar rich granite (1416).

\section{ANALYTICAL TECHNIQUES}




\section{Thin section preparation}

A segment of each of the rock samples was mounted on glass slides, cut back and polished down to $30 \mu \mathrm{m}$ thickness. Polished thin sections were imaged in transmitted light (plane- and cross-polarized) using an Axio Imager II at Curtin University for entire thin section images (Supplementary Fig. A). All thin sections were carbon coated and the full thin section analyzed using a Tescan Integrated Mineral Analyzer (TIMA) at the John de Laeter Centre (JdLC), Curtin University. Backscatter electron readings were taken every $3 \mu \mathrm{m}$ and energy dispersive X-ray spectrometry (EDS) readings were taken every $27 \mu \mathrm{m}$ or when the BSE signal changed.

\section{Whole-rock geochemistry}

All samples were trimmed to remove regolith crust and a subset sent to ALS (Ireland) and/or Genalysis Ltd. (Perth, Western Australia) for major and trace element analysis. All samples were crushed using a jaw crusher and pulverized using a low-chrome steel mill to yield particles with sizes $<75 \mu \mathrm{m}$.

To determine major and most trace element concentrations, a prepared aliquot $(0.200 \mathrm{~g})$ was added to lithium metaborate flux $(0.90 \mathrm{~g})$. The sample-metaborate flux was put in a platinum crucible, mixed well and placed in a fusion machine to heat the mixture until molten to form a single homogenous hot liquid at $1000^{\circ} \mathrm{C}$. The resulting melt was then cooled into a fused disc. At ALS, the fused disc was dissolved in $100 \mathrm{~mL}$ of $4 \% \mathrm{HNO}_{3} / 2 \% \mathrm{HCl}$. Major elements were analyzed by inductively coupled plasma optical emission spectroscopy (ICP-OES) at ALS and X-ray fluorescence (XRF) at Genalysis. Trace elements were analyzed by inductively coupled plasma mass spectrometry (ICP-MS) using a single-collector quadrupole for all elements except $\mathrm{Sc}, \mathrm{V}, \mathrm{Cr}, \mathrm{Ni}, \mathrm{Cu}$ and $\mathrm{Zn}$, which were analyzed by ICP-OES. Results were subsequently corrected for spectral inter-element interferences. For major 
elements, oxide concentration was calculated from the determined elemental concentration and the result is reported in that format (Table 2, Supplementary Table A).

Base metal determination utilized a four acid digest instead of lithium metaborate fusion on an aliquot of the sample. Many sulfides and some metal oxides are only partially decomposed by the borate fusion and some elements such as cadmium and zinc can be volatilized. A prepared aliquot $(1.0 \mathrm{~g})$ was weighted directly into a $125 \mathrm{ml}$ Teflon beaker and a concentrated four-acid digest was added ( 5

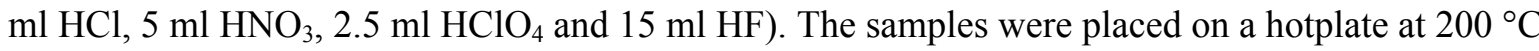
and evaporated until dry. The residue was then re-dissolved in $10 \% \mathrm{v} / \mathrm{v} \mathrm{HCl}$ and returned to the hotplate at $100^{\circ} \mathrm{C}$. When the residue was completely dissolved, the samples were cooled and transferred to $50 \mathrm{ml}$ storage tubes. One $\mathrm{ml}$ of $0.5 \% \mathrm{w} / \mathrm{v} \% \mathrm{H}_{3} \mathrm{BO}_{3}$ was added to each tube to complex $\mathrm{HCl}$ and mitigate ICP degradation. The four acid-sample solution was analyzed by ICP-MS and corrected for spectral inter-element interferences.

Loss-on-ignition was determined by placing a prepared aliquot $(1.0 \mathrm{~g})$ in an oven at $1000^{\circ} \mathrm{C}$ for one hour, cooled and then re-weighed. The percent loss on ignition is calculated from the difference in mass.

To aid in quality control, repeat major element analysis of sample 1417 revealed a $<10 \%$ discrepancy between analyses in all major element determinations (Supplementary Table A). Sample 1416 was duplicated for trace element analysis and revealed a $<5 \%$ discrepancy between analyses for most trace elements present at $>5 \mu \mathrm{g} \mathrm{g}^{-1}$ abundance, with the exception of $\mathrm{Ce}, \mathrm{Ba}$ and $\mathrm{Ga}$, which yielded differences of 6-13\% (Supplementary Table A). Elements close to the detection limit often showed significant discrepancies (Supplementary Table A). Further quality control was assured by coanalyzing standards with the unknowns, including OREAS 24b, OREAS 46 (both from the Ore Research \& Exploration, Australia) and SY-4 from Natural Resources Canada. All standard analyses overlap with certified values at $2 \sigma$ (Supplementary Table A). 


\section{Zircon separation and imaging}

Approximately $5 \mathrm{~kg}$ of each sample was crushed and the resultant slurries were put through a Wilfley concentrating shaker table for initial concentration of heavy minerals and subsequently through LST heavy liquids at $2.9 \mathrm{~g} \mathrm{~cm}^{-3}$. The heavy fraction was isolated using a Frantz isodynamic magnetic separator. Heavy mineral grains were subsequently hand-picked from the non-magnetic fraction, mounted in $25 \mathrm{~mm}$ epoxy rounds together with zircon reference standards and polished to approximately half grain thickness to expose grain interiors.

Each mount was imaged using transmitted and reflected light to provide internal grain textural information. Cathodoluminescence (CL) imaging was conducted using a Mira3 Field Emission Gun SEM (FEG-SEM) at the JdLC, Curtin University. Imaging was conducted with a nominal working distance of 15-17 mm, a beam current of $935 \mathrm{pA}$, spot size of $14 \mathrm{~nm}$ and an accelerating voltage of 12 $\mathrm{kV}$. CL images were used to document internal zonation patterns (e.g. oscillatory, sector, patchy), identify recrystallization textures and recognize the presence of any crystal rims. These identification procedures aid in elucidating whether grains were originally magmatic (igneous), metamorphic or experienced recrystallization (e.g., Corfu et al., 2003). A compendium of all mounted zircon grains may be found in Supplementary Fig. B.

\section{Zircon U-Pb geochronology and trace element geochemistry}

Zircon U-Pb and trace element data were collected at the GeoHistory Facility, JdLC, Curtin University. Most samples were analyzed in the first analytical session, with a second session performed to acquire additional analyses from sample 1416. Where possible, multiple spots were collected from both grain cores and rims. An overview of operating conditions is given here but more detail can be found in Spencer et al. (2017). The excimer laser (RESOlution LR $193 \mathrm{~nm}$ ArF with a 
Lauren Technic S155 cell) spot diameter was $33 \mu \mathrm{m}$, on-sample energy was $2 \mathrm{~J} \mathrm{~cm}^{-2}$ with a repetition rate of $5 \mathrm{~Hz}$ for 30 seconds of total of analysis time and $\sim 50$ seconds of background capture. All analyses were preceded by two cleaning pulses. The sample cell was flushed by ultrahigh purity He $\left(0.68 \mathrm{~L} \mathrm{~min}^{-1}\right)$ and $\mathrm{N}_{2}\left(2.8 \mathrm{~mL} \mathrm{~min}{ }^{-1}\right)$.

$\mathrm{U}-\mathrm{Pb}$ data were collected on an Agilent 8900 triple quadrupole mass spectrometer with high purity Ar as the carrier gas (flow rate $=0.98 \mathrm{~L}$ min-1). Analyses of every $\sim 20$ unknowns were bracketed by analyzing a standard block containing the primary zircon reference materials OG1 (3465.4 $\pm 0.6 \mathrm{Ma}$; Stern et al., 2009) and 91500 (1062.4 $\pm 0.4 \mathrm{Ma}$; Wiedenbeck et al., 1995), which were used to monitor and correct for mass fractionation and instrumental drift. The standard block also contained Plešovice (337.13 \pm 0.37 Ma; Sláma et al., 2008), GJ-1 (601.95 \pm 0.40 to $608.5 \pm 1.5 \mathrm{Ma}$; Horstwood et al., 2016, Jackson et al., 2004) and Maniitsoq (3008.70 \pm 0.72 Ma; Marsh et al., 2019; all uncertainties at $2 \sigma$ ), which were used as secondary standards to monitor data accuracy and precision. When reduced to an appropriate primary standard, all secondary standards yielded weighted mean ages within $2 \sigma$ of the published ages, including Plešovice (337.7 \pm 1.3 and $337.8 \pm 1.2 \mathrm{Ma}), \mathrm{GJ}-1$ $(603.7 \pm 1.5$ and $605.6 \pm 1.6 \mathrm{Ma})$ and Maniitsoq $(3005 \pm 5$ and $3005 \pm 7 \mathrm{Ma})$. Data were reduced using Iolite (Paton et al., 2011) and in-house Excel macros. Zircon analyses are considered concordant where the error ellipses at $2 \sigma$ generated by the ${ }^{207} \mathrm{~Pb} / 206 \mathrm{~Pb}$ and ${ }^{206} \mathrm{~Pb} / 238 \mathrm{U}$ ratios overlap the inverse concordia curve, excluding uncertainties on the decay constant (i.e., assuming the concordia curve is a line rather than a zone). Uncertainties on the primary reference materials were propagated in quadrature to the unknowns and secondary zircon reference materials. All zircon dates are presented as ${ }^{207} \mathrm{~Pb} / 206 \mathrm{~Pb}$ ages due to their superior precision at the typical ages of ca. $3 \mathrm{Ga}$. Common- $\mathrm{Pb}$ was not corrected for as almost all concordant analyses have $f 206$ of $<0.1 \%$ (supplementary Table B).

Trace element data ( $\mathrm{Si}, \mathrm{Ti}, \mathrm{Y}, \mathrm{Nb}, \mathrm{Yb}$ and $\mathrm{Hf}$ ) were collected simultaneously with $\mathrm{U}-\mathrm{Pb}$ data in the first analytical session only. International reference glass NIST610 was utilized as the primary reference material for concentration determination and to correct for instrument drift (using ${ }^{91} \mathrm{Zr}$ as the 
internal standard element and an assumed stoichiometric $43.14 \mathrm{wt}$ \% $\mathrm{Zr}$ in zircon). NIST SRM 612 was run as a secondary standard and yielded recommended values within $3 \%$ for all elements using NIST 610 as the primary reference material.

Ti-in-zircon temperatures were calculated using the method of Ferry and Watson (2007). Titanite (and/or ilmenite) and quartz are commonly observed to coexist in the analyzed samples, except samples 873 (trondhjemite) and 1416 (granite), where titanite is $<0.01$ vol. \% (Fig. 4, Table 2). Given the lack of rutile, the activation energy of $\mathrm{TiO} 2\left(\alpha_{\mathrm{TiO} 2}\right)$ is lower than 1. Given the plausible limits of $\alpha_{\mathrm{TiO} 2}=0.5$ in crustal rocks (Ferry \& Watson, 2007, Hayden \& Watson, 2007), the maximum likely overestimation of crystallization temperature would be $\sim 30^{\circ} \mathrm{C}$ at temperatures of $\sim 700-900{ }^{\circ} \mathrm{C}$ and 0.5-1.0 GPa (estimates of temperature and pressure for the Akia Terrane at ca. 3.0 Ga from Kirkland et al., 2020, Yakymchuk et al., 2020). As it is likely that the temperature and pressure did not significantly change for the age window in which the trondhjemite to granite wasemplaced, we use a constant pressure of $0.5 \mathrm{GPa}$ for all data. Temperature estimates may be overestimated by up to $\sim 30$ ${ }^{\circ} \mathrm{C}$ due to the absence of rutile, and underestimated by up to $30{ }^{\circ} \mathrm{C}$ due to potential higher pressures (up to $1.0 \mathrm{GPa}$ ). Thus, the zircon crystallization temperatures may be in error by up to $60{ }^{\circ} \mathrm{C}$.

Full zircon isotopic and trace element data for the samples are given in Supplementary Table B.

\section{RESULTS}

\section{Thin section petrography and rock classification}

The dominant country rock at both localities is a coarse-grained, leucocratic, porphyritic trondhjemite gneiss that chiefly comprises $\sim 2-5 \mathrm{~mm}$ oligoclase phenocrysts set within a coarse-grained matrix of oligoclase and quartz (Figs. 4, 5, Table 1). Samples 871, 873 and 1415 were collected from this rock type. Oligoclase phenocrysts commonly show cores or inclusions of orthoclase and albite, which 
range from rare in sample 871 to common in sample 873 (Fig. 4). Gneissic banding is poorly-defined by oligoclase + orthoclase (42-61 vol. \%) and quartz (28-34 vol. \%) layers (Fig. 4, Table 1). Minor interstitial muscovite (1.5-2.5 vol. \%) and biotite ( $0.8-1.8$ vol. \%), and trace amounts of calcite, zircon, apatite, titanite and allanite are also present (Table 1).

The trondhjemite gneiss is intruded by equigranular, mesocratic, fine- to medium-grained trondhjemitic to granodioritic gneisses. Samples 872 and 1417 were collected from this lithology. Given that the thin sections are not fully representative of the coarse-grained lithologies, these trondhjemitic to granodioritic gneisses are hereafter referred to as mesocratic granodiorite for the purposes of differentiating them from the leucocratic trondhjemites. The granodiorites have similar proportions of feldspar (52-61 vol. \%) and quartz (26-32 vol. \%) to the leucocratic trondhjemites but contain an order of magnitude more biotite ( $\sim 5-9$ vol. \% compared to $0.8-1.8$ vol. \%) that, together with their finer grain-size, yield darker coloured rocks. Minor muscovite and the same trace minerals as the leucocratic trondhjemites are also present.

The ptygmatically-folded K-feldspar rich granitoid is a coarse- to very coarse-grained, equigranular, folded, leucocratic granitic gneiss. Sample 1416 was collected from this lithology. Parts of the granitic gneiss are similar to the trondhjemite, comprising oligoclase ( \pm orthoclase) and quartz rich layers that define the foliation. However, other gneissic layers comprise orthoclase cores with albite rims. Thus, despite the fact that orthoclase and albite modal abundances are similar in samples 1416 (granite) and 873 (trondhjemite; cf. Table 1), their distributions within the rocks are different (Fig. 4); in sample 1416, orthoclase and albite are only located in the left area of the thin section (Fig. 4f), whereas in 873, orthoclase and albite are relatively evenly distributed throughout (Supplementary Fig. A). The granitic gneiss approaches granite compositions but plots in the range of granodiorite on a QPA diagram in the trondhjemite field on an Ab-An-Or diagram (Fig. 5b). Owing to their high Si content (see section 5.2) and high concentrations of albite and K-feldspar, we hereafter refer to the leucocratic granitic gneiss as granite to differentiate it from the other two lithologies. Trace minerals in the 
granite are less abundant than in other rock types, including less titanite $(<0.005$ vol. \%), zircon $(<0.007$ vol. $\%)$ and apatite $(<0.010$ vol. \%; Table 1$)$.

\section{Whole-rock major and trace element geochemistry}

All granitoid samples have negligible alteration as indicated by loss-on-ignition in all samples $<0.2$ wt. \% (Table 2). Thus, all their major and trace elements are considered to be unaffected by deuteric alteration. Major and trace elements from this study (Fig. 6) are shown together with other regional samples from the Akia Terrane to facilitate geochemical modelling (see discussion), with samples ranging from mafic amphibolites, to andesites and TTGs (Garde, 2007, Gardiner et al., 2019b, Yakymchuk et al., 2020).

The trondhjemites from this study are $\mathrm{SiO}_{2}$-rich (73.7-75.0 wt. \%) and weakly peraluminous with moderate $\mathrm{K}_{2} \mathrm{O}$ (2.3-3.1 wt. \%), low $\mathrm{K}_{2} \mathrm{O} / \mathrm{Na}_{2} \mathrm{O}(0.44-0.70$ wt. \%), low $\mathrm{CaO}(1.5-1.8$ wt. \%) and low $\mathrm{MgO}$ (0.13-0.20 wt. \%; Fig. 6; Table 2). The granodiorites are more primitive with less $\mathrm{SiO}_{2}(69.0-$ 70.8 wt. \%), more $\mathrm{MgO}\left(0.66-0.92\right.$ wt. \%), more $\mathrm{FeO}^{\mathrm{T}}$ (2.6-2.9 wt. \%) and more $\mathrm{CaO}$ (2.3-2.8 wt. \%) but are otherwise similar in major element composition to the leucocratic trondhjemites (Fig. 6; Table 2). The granite sample is the most evolved with very high $\mathrm{SiO}_{2}(\sim 76.9$ wt. \%), and extremely low $\mathrm{FeO}^{\mathrm{T}}\left(0.6\right.$ wt. \%), $\mathrm{MgO}\left(0.05\right.$ wt. \%) and $\mathrm{TiO}_{2}(0.01$ wt. \%, Fig. 6, Table 2). Most major elements show evolution trends with $\mathrm{SiO}_{2}$, consistent with liquid lines of descent, except $\mathrm{Na}_{2} \mathrm{O}, \mathrm{K}_{2} \mathrm{O}$ and equivalent +1 and +2 cation trace elements (e.g., $\mathrm{Rb}, \mathrm{Sr}$, Fig. 6, Table 2).

All samples show similar highly negatively-sloping rare earth element (REE, $[\mathrm{La} / \mathrm{Yb}] \mathrm{cn}=36-208$, where $\mathrm{cn}=$ chondrite normalized with values from Sun \& McDonough, 1989) and incompatible element (IE) plots with notable negative $\mathrm{Cs}, \mathrm{Rb}, \mathrm{U}, \mathrm{Nb}$ and $\mathrm{P}$ anomalies relative to primitive mantle (Figs. 6, 7). Europium anomalies are consistently positive for both trondhjemites and granite 
$\left(\left[\mathrm{Eu} / \mathrm{Eu}^{*}\right]_{\mathrm{cn}}=1.2-2.7\right.$, where $\left.\mathrm{Eu}^{*}=\sqrt{ }[\mathrm{Sm} \times \mathrm{Gd}]\right)$ but consistently negative for granodiorites $\left(\left[\mathrm{Eu} / \mathrm{Eu}^{*}\right]_{\mathrm{cn}}=0.71-0.74\right.$, Fig. 6$)$.

Zirconium concentrations in all samples are below continental crustal averages of $145-165 \mu \mathrm{g} \mathrm{g}^{-1}$ for Archean rocks (Fig. 6; e.g., Condie, 1993, Martin et al., 2005). Granodiorite concentrations are approximately two-thirds of average continental crust at $\sim 99-107 \mu \mathrm{g} \mathrm{g}^{-1}$, whereas trondhjemite samples have significantly lower $\mathrm{Zr}$ concentrations at $\sim 22-65 \mu \mathrm{g} \mathrm{g}^{-1}$ (Fig. 6; Table 2). Given the major element concentrations, the low $\mathrm{Zr}$ concentrations in the trondhjemites and granodiorites yielded zircon saturation temperatures $\left(\mathrm{T}_{\text {ZircSat }}\right.$ ) of $\sim 580-650{ }^{\circ} \mathrm{C}$ and $\sim 690{ }^{\circ} \mathrm{C}$, respectively (calculations using formula in Boehnke et al., 2013). The granite yielded an extremely low Zr concentration of $\sim 6 \mu \mathrm{g} \mathrm{g}^{-1}$, equivalent to a $\mathrm{T}_{\text {Zirsat }}$ of $\sim 490^{\circ} \mathrm{C}$. Such temperatures are well below the wet granite solidus. Zircon saturation calculations are most robust when applied to glasses and thus problematic for plutonic rocks (Boehnke et al., 2013, Gervasoni et al., 2016, Harrison et al., 2007). Thus, these zircon saturation temperatures are unrealistic.

\section{Zircon morphology and textures}

The zircon grains from all six samples can be subdivided into five main groups on the basis of their external morphology, habit and size, internal CL zonation, trace element chemistry (see section 5.4) and $\mathrm{U}-\mathrm{Pb}$ dates (see section 5.4): Groups 1-5 (Fig. 8, Table 3).

Zircon grains in Group 1 are anhedral to euhedral, 80-200 $\mu \mathrm{m}$-long and have aspect ratios of 1:1 to 2:1 (Fig. 8a-b). In CL, internal zircon textures are commonly homogeneous, with occasional faint oscillatory or sector zoning (Fig. 8a-b). The only difference in Group 1 grains is that in the granodiorite and granite, Group 1 grains are typically rounded cores that are always overgrown by oscillatory-zoned zircon (Fig. 8b). In the trondhjemite, Group 1 grains show no core-rim relationships (Fig. 8a) 
Group 2 occurs in granodiorite and granite (Fig. 6c-d) and comprise zircon crystals that are euhedral to subhedral, 75-150 $\mu \mathrm{m}$-long and have aspect ratios of 1:1 to 4:1 (Fig. 8c-d). In CL, Group 2 grains show well-developed oscillatory zoning with occasional thin, bright rims $(<15 \mu \mathrm{m}$ wide; Fig. $8 \mathrm{c}-\mathrm{d})$. Crystals in Group 2 have similar internal textures to Group 1 but have significantly different ages (see section 5.4, Table 3).

Group 3 grains also occur in granodiorite and granite samples. These grains are morphologically similar to Group 2, being euhedral to subhedral, 120-150 $\mu \mathrm{m}$-long and have length to width ratios of 1:1 to 3:1 (Fig. 8e-f). They differ from Group 2 in CL, displaying well-developed oscillatory- and sector-zoning with internal zones that are significantly brighter than any of the other groups (Fig. 8ef). However, oscillatory zoning towards the edge of the grains is commonly darker in CL (Fig. 8e-f). There are also thin rims $(<25 \mu \mathrm{m})$ present on Group 4 grains that are equally bright in CL in sample 1416 (e.g. Fig. 8i, far right grain 17), and these may be equivalent to Group 3.

Group 4 is present in every sample except 1417 . Group 4 comprises anhedral to subhedral zircon grains, $\sim 150-400 \mu \mathrm{m}$-long with aspect ratios of 2:1 to 4:1 (Fig. 8g-i). Zircon grains from Group 4 tend to be larger and more elongated than crystals from other groups. In CL, Group 4 crystals show variable degrees of mottling in the core and rim, which commonly overprints oscillatory zonation (Fig. 8g-i). Bright rims also occasionally occur on anhedral cores (Fig. 8i).

Group 5 is present in most samples and comprises anhedral to euhedral, 200-300 $\mu \mathrm{m}$-long zircon grains with aspect ratios of 2:1 to 3:1 (Fig. 8j). In CL, zircon gains show extremely mottled to occasionally near-homogeneous internal textures (Fig. 8j).

\section{Zircon $\mathrm{U}-\mathrm{Pb}$ isotopes and trace element data}


Analyses and ages for each of the individual samples may be found in Fig. 9. Analyses that do not overlap with the concordia or are mixed core-rim ablations are not considered further. On the basis of characteristic textural, chemical and U-Pb characteristics (Table 3), we present all U-Pb per textural grouping (Fig. 10) and report the differences between groupings below. All analyses reported below are from grain cores; analyses of thin, bright rims in sample 1416 were attempted (e.g., 1416-17 in Fig. 8c) but failed to yield any concordant analyses (supplementary Table B). All uncertainties presented in the text are at $2 \sigma$ internal for individual analyses and $95 \%$ confidence for weighted mean ages.

Zircon grains from Group 1 yielded ${ }^{207} \mathrm{~Pb} /{ }^{206} \mathrm{~Pb}$ dates from $3027 \pm 25 \mathrm{Ma}$ to $2986 \pm 23 \mathrm{Ma}$ (Table 3, Fig. 10a, Supplementary Table B). All grains from Group 1 in the trondhjemite and granodiorite/granite yielded ${ }^{207} \mathrm{~Pb} / 206 \mathrm{~Pb}$ weighted mean ages of $3011 \pm 5 \mathrm{Ma}(n=21, \mathrm{MSWD}=0.61$, $p=0.91)$ and $3008 \pm 6(n=13, \operatorname{MSWD}=0.96, p=0.48)$, respectively, which overlap at $2 \sigma$ confidence. Zircon grains in Group 1 have low to moderate U concentrations (66-385 $\mu \mathrm{g} \mathrm{g}^{-1}$, median $\left.=123 \mu \mathrm{g} \mathrm{g}^{-1}\right)$ and variably low to high $\mathrm{Th} / \mathrm{U}$ ratios $(0.28-7.2$, average $=1.9)$. Ti-in-zircon temperatures are between $628 \pm 22$ and $797 \pm 80^{\circ} \mathrm{C}\left(\right.$ median $\left.=724{ }^{\circ} \mathrm{C}\right)$.

Zircon grains from Group 2 yielded ${ }^{207} \mathrm{~Pb} /{ }^{206} \mathrm{~Pb}$ dates from $2991 \pm 21$ Ma to $2957 \pm 22 \mathrm{Ma}$, (Table 3, Fig. 10b, Supplementary Table B). Analyses from Group 2 in the granodiorite and granite yielded ${ }^{207} \mathrm{~Pb} /{ }^{206} \mathrm{~Pb}$ weighted mean ages of $2976 \pm 4 \mathrm{Ma}(n=25, \mathrm{MSWD}=0.76, p=0.79)$ and $2966 \pm 9 \mathrm{Ma}(n$ $=4, \operatorname{MSWD}=0.30, p=0.82)$, respectively, which overlap at $2 \sigma$ confidence. $\mathrm{U}$ concentrations $(82-$ $\left.449 \mu \mathrm{g} \mathrm{g}^{-1}\right)$ and $\mathrm{Th} / \mathrm{U}$ ratios (0.80-2.4) are similar to Group 1 albeit with a slightly larger spread in $\mathrm{Th} / \mathrm{U}$. Ti concentrations are more variable, with most analyses between 1.7 and $59 \mu \mathrm{g} \mathrm{g}^{-1}$, yielding Tiin-zircon temperature estimates of $605-925^{\circ} \mathrm{C}$.

Zircon grains from Group 3 yielded relatively imprecise ${ }^{207} \mathrm{~Pb} /{ }^{206} \mathrm{~Pb}$ dates from $3014 \pm 31 \mathrm{Ma}$ to 2959 $\pm 27 \mathrm{Ma}$ (Table 3, Fig. 10c, Supplementary Table B). Group 3 grains from the granodiorite and 
granite yielded ${ }^{207} \mathrm{~Pb} / 206 \mathrm{~Pb}$ weighted mean ages of $2984 \pm 15 \mathrm{Ma}(n=9, \mathrm{MSWD}=2.0, p=0.04)$ and $2979 \pm 20(n=5$, MSWD $=1.7, p=0.16)$, respectively, which overlap at $2 \sigma$ confidence and overlap with the ages from Group 2. All these grains have low $\mathrm{U}$ concentrations $\left(27-82 \mu \mathrm{g} \mathrm{g}^{-1}\right)$ and moderate to high $\mathrm{Th} / \mathrm{U}$ ratios (1.2-5.0), which explains their relatively imprecise $\mathrm{U}-\mathrm{Pb}$ dates. Ti concentrations are consistently low $\left(4.4-14.5 \mu \mathrm{g} \mathrm{g}^{-1}\right)$ that translate to Ti-in-zircon temperatures of $674 \pm 67$ to $774 \pm$ $15{ }^{\circ} \mathrm{C}$.

Group 4 grains, which show various degrees of mottling and partial resorption, yielded ${ }^{207} \mathrm{~Pb} /{ }^{206} \mathrm{~Pb}$ dates from $3066 \pm 24$ Ma to $3005 \pm 19$ Ma across five of the six samples (Table 3, Fig. 10d, Supplementary Table B). The Group 4 grains yielded a ${ }^{207} \mathrm{~Pb} /{ }^{206} \mathrm{~Pb}$ weighted mean age of $3037 \pm 5 \mathrm{Ma}$ $(n=31, \operatorname{MSWD}=2.0, p=0.001)$ but we note that this is not statistically valid for a single data set. Zircon grains in Group 4 have moderate to very high $\mathrm{U}$ concentrations $\left(102-1538 \mu \mathrm{g} \mathrm{g}^{-1}\right.$, median $=$ $\left.718 \mu \mathrm{g} \mathrm{g}^{-1}\right)$ and very low to moderate $\mathrm{Th} / \mathrm{U}$ ratios $(0.03-2.1$, median $=0.34)$. Ti concentrations also vary by two to three orders of magnitude, from 2.6 to $35 \mu \mathrm{g} \mathrm{g}^{-1}(n=25$, with three outliers at 124,195 and $\left.611 \mu \mathrm{g} \mathrm{g}^{-1}\right)$, which yield Ti-in-zircon temperature estimates of $635 \pm 64$ to $865 \pm 15{ }^{\circ} \mathrm{C}$ (median $=$ $726^{\circ} \mathrm{C}$, excluding the three outliers).

Group 5 grains have variable ${ }^{207} \mathrm{~Pb} /{ }^{206} \mathrm{~Pb}$ dates from $3020 \pm 20$ to $2832 \pm 20$ Ma with no statisticallysignificant mean (Table 3, Fig. 10e, Supplementary Table B). These grains have very high concentrations of $\mathrm{U}$ from 1275 to $3378 \mu \mathrm{g} \mathrm{g}^{-1}$ that make these zircon grains particularly susceptible to metamictization and (partial) isotopic resetting.

\section{DISCUSSION}

\section{Assigning absolute ages to granitoids}


Field mapping has identified three distinct generations of granitoids, from oldest to youngest, trondhjemite, granodiorite and granite (Fig. 3). These field observations are, to some degree, in agreement with the calculated zircon U-Pb ages. However, none of the samples yielded a single statistically coherent fraction of zircon $\mathrm{U}-\mathrm{Pb}$ dates (i.e., $p \geq 0.05$ ) compatible with solely autocrystic origin (Fig. 9). We show below that the mixture of zircon fractions can primarily be attributed to various inherited zircon reservoirs mixing with autocrystic fractions, where only the latter can be used to determine the timing of magmatic crystallization.

\section{Groups 4 and 5 - inherited fractions}

In most samples, Group 4 shows textural and chemical evidence for being out of chemical equilibrium for at least some of its history within a silicate melt. Texturally, zircon grains show mottled textures, partial to complete destruction of oscillatory- and sector-zoning and resorbed grain edges (Fig. 8g-i). Chemically, there is a significant disequilibrium between, for example, $\mathrm{Th} / \mathrm{U}$ ratios in the zircon crystals versus that in the bulk rock (see section 6.2 and Fig. 12). The ${ }^{207} \mathrm{~Pb} /{ }^{206} \mathrm{~Pb}$ dates for these zircon components range from $3066 \pm 24$ Ma to $3005 \pm 19$ Ma, statistically too varied for a single dataset with errors accounted for by analytical uncertainty alone (Fig. 10d). The heterogeneity in zircon trace element concentrations also points to several different inherited zircon reservoirs (Fig. 11). Ultimately, zircon grains from Group 4 cannot be interpreted as autocrystic and therefore do not provide information on granitoid crystallization ages.

Group 5 is similar in texture to Group 4 but even more internally chaotic (Fig. 8j). Group 5 also often displays homogeneous CL textures because its extremely high $U$ and Th concentrations suppress CL response (Nasdala et al., 2003). The chaotic to homogeneous internal textures (Fig. 8j) and the extremely high $\mathrm{U}$ and Th concentrations (Fig. 11) are consistent with these grains developing high alpha doses and thus radiation damage, leading to radiogenic $\mathrm{Pb}$-loss and isotopic resetting (Ashwal et al., 1999, Cherniak \& Watson, 2001). Given that the Akia Terrane has experienced upper amphibolite 
and granulite facies events (Garde et al., 2000, Kirkland et al., 2020, Kirkland et al., 2018a, Kirkland et al., 2018b, Yakymchuk et al., 2020), it is not surprising that Group 5 grains have undergone partial radiogenic $\mathrm{Pb}$ loss to younger apparent $\mathrm{U}-\mathrm{Pb}$ dates as elevated temperatures, fluids and radiation damage facilitate Pb mobility (Cherniak, 2010, Cherniak \& Watson, 2001, Geisler et al., 2007, Peterman et al., 2016). Like Group 4, U-Pb dates from Group 5 grains do not reflect the magmatic crystallization ages of their host rocks.

\section{Trondhjemite - crystallization revealed by Group 1}

With Groups 4 and 5 aside, it is now evident that the trondhjemite host rock (samples 871,873 and 1415 ) comprises a single autocrystic zircon group (1) with a statistically-valid ${ }^{207} \mathrm{~Pb} / 206 \mathrm{~Pb}$ weighted mean age of $3011 \pm 5 \mathrm{Ma}(n=21, \mathrm{MSWD}=0.61, p=0.91$, Fig. 10a $)$. The presence of oscillatoryand sector-zoning are indicative of magmatic crystallization processes (Fig. 8a-b). The lack of postcrystallization destruction of primary igneous zones, the lack of resorbed grain edges and the absence of grain rims indicates that this age of ca. 3010 Ma represents the crystallization age of the trondhjemite.

\section{Granodiorite - crystallization revealed by Groups 2 and 3}

Granodiorite dykes (samples 872 and 1417) comprise three zircon fractions denoted as Groups 1, 2 and 3. The textural, morphological, trace element and $\mathrm{U}-\mathrm{Pb}$ data of Group 1 grains indicate that this group is equivalent to Group 1 in the trondhjemite (Fig. 8a-b, Fig. 10a, Table 3). Thus, Group 1 grains in the granodiorite represents inherited zircon from the trondhjemite that has been incorporated into the granodiorite melt.

Groups 2 and 3 in the granodiorite are two fractions distinguished via CL response (Fig. 8fc-d) and trace element concentrations (Fig. 11) but with similar U-Pb dates at $2 \sigma$ uncertainty (Fig. 10b-c). Group 2 has significantly higher concentrations of trace elements (e.g., Hf, Nb, U), which suppresses 
the CL response and produces overall lower CL emission textures (Fig. 11). In all other aspects, Groups 2 and 3 are comparable. Similar Ti-in-zircon temperatures between Groups 2 and 3 imply that both zircon groups crystallized at approximately the same temperature (Fig. 11d). Similar incompatible element ratios (e.g., Y/Yb; Fig. 11i) imply that fractional crystallization, which has limited effect on ratios of similarly incompatible element, is the primary reason for the differences in chemistry and texture of Groups 2 and 3.

With the above considerations, we suggest that both Groups 2 and 3 in the granodiorite are probably part of the same magmatic system, with zircon grains forming at slightly different times and from slightly different source chemical compositions (cf. Schaltegger \& Davies, 2017). The magmatic system may have been partially open to magma recharge at various times, as implied by oscillatoryzoned zircon textures (Fig. 8c-d; Hoskin, 2000), but generally moving towards a closed system from the broad evolution of dark to lighter CL responses (Fig. 8c-d) and corresponding depletions in trace elements (Fig. 8c-d).

Ultimately, there is no noticeable difference in dates between Groups 2 and 3 and thus we cannot differentiate between ante- and autocrystic fractions. A combined ${ }^{207} \mathrm{~Pb} / 206 \mathrm{~Pb}$ weighted mean age of $2978 \pm 4(n=34, \operatorname{MSWD}=1.12, p=0.29$, Fig. $10 \mathrm{~b}-\mathrm{c})$ for Groups 2 and 3 is considered the best age estimate for crystallization of the granodiorite dykes. This age is also comparable to the ca. $2970 \mathrm{Ma}$ age previously determined from granodiorite intrusions at locality 1 by Scherstén and Garde (2013; sample 524254).

\section{K-feldspar granite - solely inherited crystals}

The K-feldspar rich granite (sample 1416) is enigmatic in that it only comprises zircon grains with the same morphological, textural, chemical and age characteristics as those found in samples of the surrounding trondhjemite and granodiorite (Fig. 8-10). Although Group 4 shows evidence of inheritance (e.g., mottling, partial resorption, Fig. 8c), Groups 2 and 3 are texturally indicative of 
magmatic zircons (Corfu et al., 2003), with no clear evidence of partial resorption or overprinting of primary oscillatory- or sector-zoning (Fig. 8g,i). Yet, the chemistry and U-Pb dates of Groups 2 and 3 in the granite can be clearly linked to the same groups in the granodiorite, overlapping in age (Figs. $10,11)$.

Without the trondhjemite and granodiorite geochronology it would have been difficult, if not impossible, to ascertain that Groups 2 and 3 in the granite were inherited and not autocrystic. The age of the granite (sample 1416) would conceivably have been erroneously interpreted as the age of the youngest zircon fraction. Instead, all the analyses record zircon inheritance. Therefore, we can only ascertain that the granite is younger than the granodiorite based on cross-cutting relationships (i.e., younger than ca. $2978 \mathrm{Ma}$, Fig. 10b-c). As the magmatic rims did not yield concordant analyses, it is uncertain how much younger the granite is.

\section{Th/U disequilibrium in inherited zircon grains}

Above, we have shown that sufficient textural, chemical and age evidence exists for differentiating inherited from autocrystic grains. In addition, there are indications that there is a significant imbalance of $\mathrm{Th} / \mathrm{U}$ ratios in the zircon crystals versus the bulk rock (Fig. 12). Work by Kirkland et al. (2015) on $>10,000$ magmatic zircon grains from Western Australia established a distinct relationship between Ti-in zircon crystallization temperature and $\mathrm{Th}_{\text {(zircon/rock) }} / \mathrm{U}_{\text {(zircon/rock). }}$ Kirkland et al., (2015) predicted the $\mathrm{Th}_{\text {(zircon/rock) }} / \mathrm{U}_{\text {(zircon/rock) }}$ ratio under equilibrium crystallization conditions and suggested that autocrystic zircon grains plot between the equilibrium crystallization curve - where zircon is in equilibrium with the silicate melt - and a fractionation trend with a high correlation coefficient towards lower $\mathrm{Th}_{\text {(zircon/rock) }} / \mathrm{U}_{\text {(zircon/rock) }}$ (Fig. 12a). Conversely, antecrystic grains were suggested to plot above the equilibrium crystallization curve, indicating that these formed at high temperatures and prior to significant fractionation (Fig. 11a; Kirkland et al., 2015). Siégel et al. (2018) found slightly 
different relationships in a zircon dataset from eastern Australia but produced a similar equilibrium crystallization curve, some $50{ }^{\circ} \mathrm{C}$ lower for a given $\mathrm{Th}_{\text {(zircon/rock) }} / \mathrm{U}_{\text {(zircon/rock) }}$ at $\sim 700{ }^{\circ} \mathrm{C}$ (see Fig. $8 \mathrm{~B}$ of Siégel et al., 2018). Given the uncertainties associated with $\mathrm{Th} / \mathrm{U}$ concentrations in whole rocks (see below; Table 2), a $50{ }^{\circ} \mathrm{C}$ difference is within uncertainty of the modeling technique.

In our dataset, the autocrystic grains (i.e., Group 1 in the trondhjemite, Groups 2 and 3 in the granodiorite) mimic the autocryst fractionation trend identified by Kirkland et al. (2015) (Fig. 12a). There are minor differences in whole-rock $\mathrm{Th} / \mathrm{U}$ ratios in the trondhjemite (18-28) and granodiorite (10-20) but these make little difference to the logarithmically-plotted $\mathrm{Th}_{\text {(zircon/rock) }} / \mathrm{U}_{\text {(zircon/rock) }}$ ratios (Fig. 12). Both the trondhjemite and granodiorite show moderate correlations $\left(\mathrm{R}^{2}=0.30\right.$ and 0.20 , respectively), which intersect the equilibrium crystallization curve at temperatures of 830 and $780{ }^{\circ} \mathrm{C}$, respectively (Fig. 12a). The spread in data is possibly a reflection of slight $\mathrm{Th} / \mathrm{U}$ ratio differences between the individual fractionated crystals' melt composition and the measured whole rock concentration (as a proxy for that melt). Thus, it is more conservative to estimate the crystallization temperature range from the full spectrum of data (i.e., positions where the grey field in Fig. 12a touches the equilibrium crystallization curve), which corresponds to a temperature range of $\sim 720-860$ ${ }^{\circ} \mathrm{C}$ (Fig. 12a). We see no data points plotting above the equilibrium crystallization curve and, thus, no evidence for antecrystic zircon grains (Fig. 12a).

One important implication carried with this form of evaluation of crystal geochemistry is how the $\mathrm{Th} / \mathrm{U}$ ratio in zircon versus bulk rock can be used to differentiate autocrystic versus xenocrystic and restitic zircon grains. Both xenocrystic and restitic grains are expected to be, on average, in significant disequilibrium with the silicate melt they reside in, irrespective of whether they were incorporated via partial melting of a restitic source or wall-rock assimilation. Diffusional equilibration of Th and U with the host melt is also expected to be negligible given the very slow diffusivity of actinides in zircon (Cherniak et al., 1997). Furthermore, inherited zircon would be expected to display greater variability in $\mathrm{Th}_{\text {(zircon/rock) }} / \mathrm{U}_{\text {(zircon/rock) }}$ as a function of their dissimilarity to primary melt composition 
(i.e., whole rock composition). Thus, fractional crystallization regressions through inherited components would not be well defined (i.e., low $\mathrm{R}^{2}$ ) due to this source discrepancy. This hypothesis is corroborated by both poor overlap of the inherited fraction with the field defined by autocrystic grains and poor correlation trends of the inherited grain groups $\left(\mathrm{R}^{2}<0.02\right.$, Fig. $\left.12 \mathrm{~b}\right)$.

The discrepancy between the inherited grains and the autocrystic field in Fig. 12a is especially notable for Group 4, interpreted to be derived from a restitic reservoir (Fig. 12b). Such extremely low fractionation factors are geologically unreasonable (Kirkland et al., 2015), implying that the $\mathrm{Th} / \mathrm{U}$ ratios in the restitic zircon grains cannot correspond to the $\mathrm{Th} / \mathrm{U}$ whole-rock ratios of the trondhjemite, granodiorite or granite in which the restitic zircon grains reside. Other inherited groups (Group 1 in the granodiorite and granite, and Groups 2 and 3 in the granite) deviate less from the autocrystic field (Fig. 12b), indicating that the zircon $\mathrm{Th} / \mathrm{U}$ ratios are more similar to the whole-rock $\mathrm{Th} / \mathrm{U}$ ratios of the trondhjemite, granodiorite and granite (Table 2). Nonetheless, $\mathrm{R}^{2}$ values of fits are still much less that those from autocrystic components (Fig. 12b). This technique may provide another tool for identifying inherited zircon crystals, particularly if the parent zircon source has dissimilar bulk rock $\mathrm{Th} / \mathrm{U}$ ratios to the new silicate melt.

\section{Modelling the causes for inherited zircon in granitoids}

With the ages assigned to the three sample lithologies, the addition of whole-rock geochemistry coupled with the above zircon data can be used to elucidate the processes that account for the lack of autocrystic zircon grains in the granite. The granite sample has extremely low $\mathrm{Zr}$ concentrations at $\sim 6$

$\mu \mathrm{g} \mathrm{g}^{-1}$; granitoids with such low concentrations of $\mathrm{Zr}$ are rare in the Proterozoic and Phanerozoic (Barbey et al., 1996) but more common in the Archean rock record (Van Kranendonk \& Kirkland, 2013). The low $\mathrm{Zr}$ concentrations in the granite are consistent with its lack of autocrystic zircon (Fig. 9), and the paucity of zircon grains in the sample in general (Supplementary Fig. B). In any evolved 
granitoid such as granite sample 1416 with $\sim 77$ wt. $\% \mathrm{SiO}_{2}$, it is necessary to have multiple stages of crystallization and partial melting to evolve a mantle-derived melt with $\sim 45-50 \mathrm{wt} . \% \mathrm{SiO}_{2}$ to a rock with $>75$ wt. $\% \mathrm{SiO}_{2}$ (Fig. 12; Chappell, 1974, Clemens et al., 2011, Gao et al., 2016, Soesoo, 2000). The primary mechanisms for reducing the $\mathrm{Zr}$ concentrations for highly evolved rocks is via fractional crystallization or partial melting of already Zr-depleted rocks (Lee \& Bachmann, 2014, Wu et al., 2017).

Three scenarios are considered for the inheritance of zircon grains in the granite: (i) extensive fractional crystallization of a lower crustal, mafic amphibolite, as is commonly invoked as the source for TTGs (Bédard, 2006, Condie, 2005, Gardiner et al., 2019a, Næraa et al., 2014), with additional local assimilation of wall-rock, (ii) remelting of the granodiorite and/or trondhjemite to form the granite, and (iii) fractionation of the surrounding granodiorite and/or trondhjemite.

\section{Scenario 1: Extensive fractional crystallization of a mafic amphibolite}

In the first scenario, we test whether extensive fractional crystallization of a less evolved source can generate the investigated samples by using the rhyolite-MELTS program (Gualda et al., 2012). We employ adiabatic cooling of a variably hydrated, mafic granulite from 950 to $750{ }^{\circ} \mathrm{C}$, whereby the final temperature corresponds approximately to the temperature of granite crystallization as predicted by Fig. 12. We use a mafic granulite sample (725) from Yakymchuk et al. (2020) as a starting composition as this sample is sufficiently primitive ( 48 wt. $\% \mathrm{SiO}_{2}, 18$ wt. $\% \mathrm{MgO}$, Fig. 6$)$ and is proximal to the samples studied here ( $\sim 50 \mathrm{~km}$ apart). Other magmatic samples with major and trace element data from the Akia Terrane (Garde, 2007, Gardiner et al., 2019b, Yakymchuk et al., 2020) are also shown to facilitate the modeling. The incorporation of various degrees of granodiorite or trondhjemite assimilant is not modelled because of their compositional similarity to the granite (Fig. $6)$. 
We find that fractionation at upper crustal conditions ( $\sim 3 \mathrm{kbar})$ at relatively low $\mathrm{H}_{2} \mathrm{O}$ contents of $\sim 2.0$ wt. \% best fits the various major element patterns, although $\mathrm{Al}_{2} \mathrm{O}_{3}$ is a better fit with lower water contents $\left(\mathrm{H}_{2} \mathrm{O}=0.5\right.$ wt. \%; Fig. 6). We note that rhyolite-MELTS does not model quartz or magnetite fractionation as a quartz-fayalite-magnetite buffer is assumed, which explain why the $\mathrm{MgO}$ vs $\mathrm{SiO}_{2}$ and $\mathrm{Fe}_{2} \mathrm{O}_{3}(\mathrm{t})$ values are not adequately modelled (Fig. 6). Also, rhyolite-MELTS does not model trace elements but the $\mathrm{MgO}$ vs $\mathrm{Zr}$ trend is qualitatively similar to, for example, the modelled $\mathrm{MgO}$ vs $\mathrm{TiO}_{2}$ curve (Fig. 6), the latter being related to rutile, titanite or ilmenite fractionation. It should be noted that rhyolite-MELTS does not account for the breakdown of hydrous phases (e.g., amphibole). Thus, the water content will probably vary during cooling, and this is not encapsulated in our models.

Our models indicate that fractionation of up to $85 \%$ crystals is required to yield the highly depleted samples with $>74$ wt. $\% \mathrm{SiO}_{2}$ and $<0.2$ wt. $\% \mathrm{MgO}$ (Fig. 6). Such extreme fractionation volumes are unlikely as the efficacy of crystal fractionation in felsic liquids is inhibited by both its high viscosity and the similar densities of fractionated phases (e.g., plagioclase) from the residual melt (Clemens \& Stevens, 2016).

Scenario 2: Partial melting of surrounding granodiorite or trondhjemite

In the second scenario, partial melting of the granodiorite or trondhjemite modelling cannot produce the granite. Rare earth elements are often employed for melting/fractionation modelling as they are relatively insensitive to secondary processes such as alteration and metamorphism (Jourdan et al., 2007, Olierook et al., 2018). Partial melting of the trondhjemite or granodiorite would lead to, for example, an increase in the $\mathrm{La} / \mathrm{Sm}$ and $\mathrm{La} / \mathrm{Yb}$ ratios of the resultant melt. However, the granite has even lower $\mathrm{La} / \mathrm{Sm}$ and $\mathrm{La} / \mathrm{Yb}$ than the trondhjemite and granodiorite (Fig. 6). Thus, it is not possible to generate the granite from the trondhjemite or granodiorite.

Scenario 3: Fractionation of the surrounding granodiorite or trondhjemite 
In the third scenario, the presence or absence of autocrystic zircon may reflect the fractionation of anatectic melt in the deep crust. Anatectic melt in the deep crust is generated through partial melting of high-temperature metamorphic rocks mostly through reactions associated with the breakdown of hydrated minerals (e.g., Brown, 2013, Yakymchuk, 2019). In the Akia Terrane, high-temperaturelow-pressure granulite-facies metamorphism associated with partial melting occurred at c. 3.05-2.97 Ga (Friend \& Nutman, 1994, Garde et al., 2000, Yakymchuk et al., 2020). Mesoarchean (ca. 3.0 Ga) granitoids in the western Akia Terrane have zircon Hf isotope ratios that are consistent with being derived from Eoarchean metabasites (Gardiner et al., 2019b) and have trace element compositions consistent with melt expected from partial melting of metabasites at $3-6 \mathrm{~km}$ below the current erosional level (Yakymchuk et al., 2020). Therefore, rocks exposed at the current erosional level and from the deeper crust were part of the same anatectic system at c. 3.0 Ga in the western Akia Terrane. Melt may have been generated, transported and emplaced at various levels in the partially molten deep crust without necessitating discrete partial melting and crystallization episodes as is envisaged in the first two scenarios.

During anatexis, melt initially forms at the grain boundaries between reactants; once a critical volume is reached, low-density and weak felsic melt can be extracted (e.g., Rosenberg \& Handy, 2005) and then ascend due to buoyancy or travel to nearby dilational zones. In many migmatite terranes, the majority of melt generated is expected to stay in the anatectic crust (e.g., Carvalho et al., 2016, Diener et al., 2014, Morfin et al., 2013, Yakymchuk et al., 2013). Chemical differentiation of this melt can occur during extraction, transport, and emplacement due to crystal fractionation (Morfin et al., 2014, Sawyer, 1987, Solar \& Brown, 2001). Consequently, most granitoids in anatectic terranes do not have the compositions of initial anatectic melt. The two granodiorite samples $(872,1417)$ that we investigated do not show strongly fractionated trace element patterns and are the closest approximation to the composition of initial anatectic melt expected to be generated from an anatectic metabasite (cf. Yakymchuk et al., 2020). These rocks would be expected to have igneous zircon and 
variable amounts of restitic or xenocrystic zircon depending on the efficacy of extraction from the source (i.e. entrained material) and interaction with the wall rock during transport and emplacement (i.e. assimilation).

Many granitoids in migmatite terranes are cumulates that reflect the physical accumulation of early crystallized minerals and the loss of more fractionated melt (e.g., Brown et al., 2016, Sawyer, 1987, Yakymchuk, 2019). Melt loss can be aided by syn-anatectic deformation (i.e., filter pressing; Brown et al., 1995). Considering that zircon is expected to grow early from anatectic melt in the crystallization sequence (Kelsey et al., 2008, Yakymchuk \& Brown, 2014), these rocks are expected to contain autocrystic zircon. Three trondhjemites $(871,873$ and 1415) from the Akia Terrane contain positive Eu anomalies that suggest they have more plagioclase than an initial melt composition and could be part of the cumulate suite (Fig. 7). These samples also contain autocrystic zircon as well as restitic zircon that could have been retained from the source.

The complementary fractionated melt to the cumulate-rich material in migmatites are granitoids that are leucocratic, $\mathrm{SiO}_{2}$ and $\mathrm{K}_{2} \mathrm{O}$ rich, and can have low $\left(<100 \mu \mathrm{g} \mathrm{g}^{-1}\right)$ concentrations of $\mathrm{Zr}$ (Milord et al., 2001, Morfin et al., 2014, Sawyer, 1987). These features reflect the physical separation of ferromagnesian minerals, plagioclase and potentially zircon from the anatectic melt prior to final emplacement and crystallization (e.g., Morfin et al., 2014). Even if antecrystic zircon crystallized from this melt, it may have been physically separated during extraction and remained with the complementary cumulates. $\mathrm{Zr} / \mathrm{Hf}$ ratios, an effective tool to test whether zircon has been extensively fractionated from the melt in granites (Claiborne et al., 2006), show chondritic $\mathrm{Zr} / \mathrm{Hf}$ ratios of 33.340.5 for the trondhjemite and granodiorite samples (Table 2), indicative of negligible to modest zircon fractionation (Claiborne et al., 2006). However, granite sample 1416 has a $\mathrm{Zr} / \mathrm{Hf}$ ratio of 30.0 (Table 2), significantly lower than chondrite values, and probably reflects extensive zircon fractionation. 
The final emplacement of this fractionated and Zr-depleted melt may be associated with the entrainment of xenocrystic zircon from the surrounding rocks and autocrystic zircon may be absent. Sample 1416 from this study has similar characteristics (high $\mathrm{SiO}_{2}$, high $\mathrm{K}_{2} \mathrm{O}$, leucocratic, low $\mathrm{Zr}$ ) to fractionated granite compositions in other migmatite terranes, contains xenocrysts with similar ages to those from the host granodiorite and trondhjemite (Fig. 10), and yielded no autocrystic zircon. Consequently, the early crystallization of anatectic melt and physical separation of the cumulate-rich material from the fractionated liquid may result in granitoids with very little autocrystic zircon.

To test the above ideas, we use the same MELTS model as in scenario 1 but start the fractionation from the most primitive sample in our study (granodiorite 872 with $\mathrm{MgO}=0.92$ ). Using the most primitive rock will provide the maximum fractionation expected to generate a granite. We show that the granite is best produced with $\sim 10 \%$ fractionation of granodiorite sample 872 with $2.0 \mathrm{wt} . \% \mathrm{H}_{2} \mathrm{O}$, pressures of $3 \mathrm{kbar}$ and a QFM buffer (Fig. 4, insets in $\mathrm{TiO}_{2}$ and $\mathrm{CaO}$ diagrams). If the granite was instead produced from further fractionation of one the trondhjemites, the fractionation would be $\sim 2-$ $3 \%$ only. Irrespective of which scenario is correct, a maximum of $10 \%$ fractionation is far more feasible in crustal rocks than scenario 1, which involved starting with a mafic amphibolite and fractionating $85 \%$ in a single step. Thus, fractionation from the granodiorite or trondhjemite seems plausible to generate the granite.

One final point of intrigue is how a rock with $\sim 6 \mu \mathrm{g} \mathrm{g}^{-1} \mathrm{Zr}$ managed to retain zircon crystals whilst not producing any autocrystic zircon. A Zr-saturated melt is required for the zircon to remain stable and remain in the residue during anatexis; if the melt was undersaturated, any zircon would be dissolved. In thin section, the only observed zircon crystal in sample 1416 is situated within a large plagioclase crystal (insets in Fig. 4e-f). Thus, we propose that the zircon crystals were buffered in a major phase mineral that was also inherited. Zircon crystals that were entombed in feldspar grains would be exempt from interaction with fluids, thereby preserving zircon in a $\mathrm{Zr}$-undersaturated melt. 


\section{Mechanisms for inherited zircon delivery into magmatic plumbing systems}

Our modeling indicates that the ultimate source(s) for the trondhjemites, granodiorites and granite samples in this study are all mafic amphibolites similar to sample 725 in Yakymchuk et al. (2020) (Figs. 6, 13), and this is also consistent with Hf isotopic data (Gardiner et al., 2019a). However, extensive crystal fractionation ( $\sim 85 \%)$ as presented in scenario 1 is unlikely, and a fractionation of the surrounding trondhjemite and/or granodiorite in a partially molten deep crust (scenario 3 ) is a more plausible explanation. The question remains how abundant inherited zircon was specifically incorporated into these rocks. Two primary mechanisms for delivering inherited zircon into a new magma plumbing system have been proposed: (i) derivation from partial melting of a deep, restitic source, or (ii) shallow-level wall-rock assimilation (i.e., xenocrysts, Fig. 1). We suggest that both modes have operated for delivering different zircon groups into different lithologies in our case study, and these are explored in more detail below.

Zircon found deep in the magmatic plumbing system and ascending is a common phenomenon but its unambiguous identification remains problematic (Figs. 1, 13; Miller et al., 2007). Much like sourceto-sink analysis of sedimentary rocks, having analyzed both the restite and neocrystallized igneous rocks is a requisite for unequivocal identification of restitic zircon in neocrystallized rocks (Olierook et al., 2019). In our samples, the largest fraction of inherited grains occurs in trondhjemite, with $>50 \%$ of grains belonging to Group 4 (Fig. 9a-c). Such volumes of inherited zircon are difficult to incorporate into the partial melt via late-stage crustal assimilation because granitoid mushes are not hot enough to facilitate such extensive crustal assimilation (Spera \& Bohrson, 2001) and crustal assimilation is an energy intensive and self-limiting process (Glazner, 2007). Their mottled and partially-resorbed textural evidence (Fig. 8) also points towards long-term magma interaction (e.g., Corfu et al., 2003). Excluding two younger Group 4 dates, Group 4 grains of ca. 3066-3022 Ma are common in orthogneisses across the Akia Terrane (Garde et al., 2000, Gardiner et al., 2019b), which 
may imply a widespread reservoir in the Maniitsoq region. Such a source has been found across several locations in the Akia Terrane (Fig. 13). Garde et al. (2000) reported ages of $3050 \pm 7 \mathrm{Ma}$ and $3035 \pm 7 \mathrm{Ma}$ for two retrogressed grey gneisses on the southern margin of the Akia Terrane. In the central part of the Akia Terrane, Garde et al. (2000) obtained an age of $3044 \pm 7$ Ma for a diorite in Fiskefjord. Scherstén and Garde (2013) also report a ca. 3038 Ma age from a granitoid xenolith in a postkinematic intrusion in the northeastern part of the Akia Terrane. Thus, the source of these restitic grains is probably from less evolved gneissic rocks deeper within the Akia Terrane.

For the granodiorite and granite samples, wall-rock assimilation of xenocrystic zircon is a better explanation for the origins of inherited zircon grains than restitic zircon (Fig. 13). The granodiorite samples contain only a single zircon analysis from Group 4 across both samples (Fig. 9d,e). Thus, it is unlikely that the Group 4 grains in the granodiorite were incorporated from a restitic reservoir, but rather from crustal assimilation of the trondhjemite wall-rock the granodiorite was intruding into. A crustal assimilation mechanism for the granodiorite melt also explains the presence of Group 1 grains that are interpreted to have been derived from the surrounding trondhjemite. The zircon morphologies of Group 1 grains are relatively unmodified by long-term magma-crystal interaction (Fig. 8; Corfu et al., 2003), which further supports the notion that these grains are xenocrystic rather than restitic. The lack of melt modification of zircon grains from Group 1 is probably due to the short duration of cooling and limited volume of melt, as demonstrated by the relatively thin width of the intrusions and fine- to medium-grain size of the granodiorite.

\section{CONCLUSIONS}

Two field localities with up to three lithologies in the Akia Terrane contain complex zircon populations comprising both inherited and autocrystic grains. Using textural, and zircon $\mathrm{U}-\mathrm{Pb}$ and trace element data, it is possible to differentiate inherited from autocrystic components and assign 
ages of $3011 \pm 5 \mathrm{Ma}(2 \sigma)$ for the host trondhjemite and $2978 \pm 4 \mathrm{Ma}(2 \sigma)$ for the granodiorite intrusions, compatible with the relative chronology evident in field relationships. The granite is established as the youngest lithology from cross-cutting relationships but yielded exclusively inherited zircon grains sourced from the older two lithologies, with potentially the only magmatic zircon located in $<15 \mu \mathrm{m}$ rims that could not be readily dated. Th/U ratios in zircon versus whole rock can also serve as a novel tool for differentiating autocrystic from xenocrystic and restitic zircon grains. Whole-rock geochemistry shows that the granite is highly evolved with $\mathrm{SiO}_{2}$ contents of $\sim 77 \mathrm{wt} . \%$ and exhibits extremely low concentrations of $\operatorname{Zr}\left(\sim 6 \mu \mathrm{g} \mathrm{g}^{-1}\right)$. It is likely that such low concentrations were caused by derivation from already Zr-depleted TTG suites, probably from continued fractionation of the surrounding trondhjemite and/or granodiorite. We demonstrate that inherited zircon in the three lithologies were derived from both restitic reservoirs and via wall-rock assimilation. Ultimately, we emphasize the importance of detailed field mapping, adequate sampling of all lithologies, and auxiliary zircon trace element and whole rock geochemical data to aid in the positive identification of inherited zircon.

\section{ACKNOWLEDGEMENTS}

The Maniitsoq map project is supported by the Ministry of Mineral Resources, Government of Greenland. The LA-ICP-MS instruments in the JdLC were funded via an Australian Geophysical Observing System grant provided to AuScope Pty Ltd. by the AQ44 Australian Education Investment Fund program. The manuscript benefited significantly from the detailed comments of T. Andersen and three anonymous reviewers, and the editorial handling of J. Harvey.

\section{REFERENCES}


Ashwal, L. D., Tucker, R. D. \& Zinner, E. K. (1999). Slow cooling of deep crustal granulites and Pb-loss in zircon. Geochimica et Cosmochimica Acta 63, 2839-2851.

Barbey, P., Brouand, M., Fort, P. L. \& Pêcher, A. (1996). Granite-migmatite genetic link: the example of the Manaslu granite and Tibetan Slab migmatites in central Nepal. Lithos 38, 63-79.

Barker, F. (1979). Chapter 1 - Trondhjemite: Definition, Environment and Hypotheses of Origin. In: Barker, F. (ed.) Developments in Petrology: Elsevier, 1-12.

Bea, F. (1996). Residence of REE, Y, Th and U in Granites and Crustal Protoliths; Implications for the Chemistry of Crustal Melts. Journal of Petrology 37, 521-552.

Bédard, J. H. (2006). A catalytic delamination-driven model for coupled genesis of Archaean crust and sub-continental lithospheric mantle. Geochimica et Cosmochimica Acta 70, 1188-1214.

Belousova, E., Griffin, W., O'Reilly, S. Y. \& Fisher, N. (2002). Igneous zircon: trace element composition as an indicator of source rock type. Contributions to Mineralogy and Petrology 143, 602-622.

Boehnke, P., Watson, E. B., Trail, D., Harrison, T. M. \& Schmitt, A. K. (2013). Zircon saturation rerevisited. Chemical Geology 351, 324-334.

Bridgwater, D. \& Schiotte, L. (1991). The Archaean gneiss complex of Northern Labrador-A review of current results, ideas and problems. Bulletin of the Geological Society of Denmark 39, 153-166.

Broderick, C., Wotzlaw, J. F., Frick, D. A., Gerdes, A., Ulianov, A., Günther, D. \& Schaltegger, U. (2015). Linking the thermal evolution and emplacement history of an upper-crustal pluton to its lower-crustal roots using zircon geochronology and geochemistry (southern Adamello batholith, $\mathrm{N}$. Italy). Contributions to Mineralogy and Petrology 170, 28.

Brown, C. R., Yakymchuk, C., Brown, M., Fanning, C. M., Korhonen, F. J., Piccoli, P. M. \& Siddoway, C. S. (2016). From source to sink: petrogenesis of Cretaceous anatectic granites from the Fosdick migmatite-granite complex, West Antarctica. Journal of Petrology 57, 1241-1278.

Brown, M. (2013). Granite: From genesis to emplacement. GSA Bulletin 125, 1079-1113.

Brown, M., Averkin, Y. A., McLellan, E. L. \& Sawyer, E. W. (1995). Melt segregation in migmatites. Journal of Geophysical Research: Solid Earth 100, 15655-15679.

Carvalho, B. B., Sawyer, E. W. \& Janasi, V. d. A. (2016). Crustal reworking in a shear zone: transformation of metagranite to migmatite. Journal of Metamorphic Geology 34, 237-264. Chappell, B. W. (1974). Two contrasting granite types. Pacif. Geol. 8, 173-174.

Chappell, B. W., White, A. J. R. \& Wyborn, D. (1987). The Importance of Residual Source Material (Restite) in Granite Petrogenesis. Journal of Petrology 28, 1111-1138.

Charlier, B. L. A., Wilson, C. J. N., Lowenstern, J. B., Blake, S., Van Calsteren, P. W. \& Davidson, J. P. (2005). Magma Generation at a Large, Hyperactive Silicic Volcano (Taupo, New Zealand) Revealed by $\mathrm{U}-\mathrm{Th}$ and U-Pb Systematics in Zircons. Journal of Petrology 46, 3-32.

Cherniak, D. J. (2010). Diffusion in Accessory Minerals: Zircon, Titanite, Apatite, Monazite and Xenotime. Reviews in Mineralogy and Geochemistry 72, 827-869.

Cherniak, D. J., Hanchar, J. M. \& Watson, E. B. (1997). Diffusion of tetravalent cations in zircon. Contributions to Mineralogy and Petrology 127, 383-390.

Cherniak, D. J. \& Watson, E. B. (2001). Pb diffusion in zircon. Chemical Geology 172, 5-24.

Claiborne, L. L., Miller, C. F., Flanagan, D. M., Clynne, M. A. \& Wooden, J. L. (2010). Zircon reveals protracted magma storage and recycling beneath Mount St. Helens. Geology 38, 1011-1014.

Claiborne, L. L., Miller, C. F., Walker, B. A., Wooden, J. L., Mazdab, F. K. \& Bea, F. (2006). Tracking magmatic processes through $\mathrm{Zr} / \mathrm{Hf}$ ratios in rocks and $\mathrm{Hf}$ and Ti zoning in zircons: An example from the Spirit Mountain batholith, Nevada. Mineralogical Magazine 70, 517-543.

Clarke, D. B. (2007). Assimilation of xenocrysts in granitic magmas: Principles, processes, proxies, and problems. The Canadian Mineralogist 45, 5-30. 
Clemens, J. D. \& Stevens, G. (2016). Melt segregation and magma interactions during crustal melting: Breaking out of the matrix. Earth-Science Reviews 160, 333-349.

Clemens, J. D., Stevens, G. \& Farina, F. (2011). The enigmatic sources of I-type granites: The peritectic connexion. Lithos 126, 174-181.

Condie, K. C. (1993). Chemical composition and evolution of the upper continental crust: Contrasting results from surface samples and shales. Chemical Geology 104, 1-37.

Condie, K. C. (2005). TTGs and adakites: are they both slab melts? Lithos 80, 33-44.

Corfu, F., Hanchar, J. M., Hoskin, P. W. O. \& Kinny, P. (2003). Atlas of Zircon Textures. Reviews in Mineralogy and Geochemistry 53, 469-500.

Diener, J. F. A., White, R. W. \& Hudson, T. J. M. (2014). Melt production, redistribution and accumulation in mid-crustal source rocks, with implications for crustal-scale melt transfer. Lithos 200, 212-225.

Eliasson, T. \& Schöberg, H. (1991). U-Pb dating of the post-kinematic Sveconorwegian (Grenvillian) Bohus granite, SW Sweden: evidence of restitic zircon. Precambrian Research 51, 337-350.

Ferry, J. M. \& Watson, E. B. (2007). New thermodynamic models and revised calibrations for the Tiin-zircon and Zr-in-rutile thermometers. Contributions to Mineralogy and Petrology 154, 429-437.

Friend, C. \& Kinny, P. (2001). A reappraisal of the Lewisian Gneiss Complex: geochronological evidence for its tectonic assembly from disparate terranes in the Proterozoic. Contributions to Mineralogy and Petrology 142, 198-218.

Friend, C. R. L. \& Nutman, A. P. (1994). Two Archaean granulite-facies metamorphic events in the Nuuk-Maniitsoq region, southern West Greenland: correlation with the Saglek block, Labrador. Journal of the Geological Society 151, 421-424.

Friend, C. R. L. \& Nutman, A. P. (2005). New pieces to the Archaean terrane jigsaw puzzle in the Nuuk region, southern West Greenland: steps in transforming a simple insight into a complex regional tectonothermal model. Journal of the Geological Society 162, 147-162.

Friend, C. R. L., Nutman, A. P. \& McGregor, V. R. (1988). Late Archaean terrane accretion in the Godthåb region, southern West Greenland. Nature 335, 535-538.

Gao, P., Zheng, Y. F. \& Zhao, Z. F. (2016). Experimental melts from crustal rocks: A lithochemical constraint on granite petrogenesis. Lithos 266-267, 133-157.

Garde, A. A. (1997). Accretion and evolution of an Archaean high-grade grey gneiss-amphibolite complex: the Fiskefjord area, southern West Greenland.

Garde, A. A. (2007). A mid-Archaean island arc complex in the eastern Akia terrane, Godthåbsfjord, southern West Greenland. Journal of the Geological Society 164, 565-579.

Garde, A. A., Friend, C. R. L., Nutman, A. P. \& Marker, M. (2000). Rapid maturation and stabilisation of middle Archaean continental crust: the Akia terrane, southern West Greenland. Bulletin of the Geological Society of Denmark 47, 1-27.

Gardiner, N. J., Johnson, T. E., Kirkland, C. L. \& Szilas, K. (2019a). Modelling the Hafnium-Neodymium evolution of early earth: a study from West Greenland. Journal of Petrology 60, 177-197.

Gardiner, N. J., Kirkland, C. L., Hollis, J., Szilas, K., Steenfelt, A., Yakymchuk, C. \& Heide-Jørgensen, H. (2019b). Building Mesoarchaean crust upon Eoarchaean roots: the Akia Terrane, West Greenland. Contributions to Mineralogy and Petrology 174, 20.

Geisler, T., Schaltegger, U. \& Tomaschek, F. (2007). Re-equilibration of zircon in aqueous fluids and melts. Elements 3, 43-50.

Gervasoni, F., Klemme, S., Rocha-Júnior, E. R. V. \& Berndt, J. (2016). Zircon saturation in silicate melts: a new and improved model for aluminous and alkaline melts. Contributions to Mineralogy and Petrology 171, 21.

Glazner, A. F. (2007). Thermal limitations on incorporation of wall rock into magma. Geology 35, 319322. 
Gualda, G. A. R., Ghiorso, M. S., Lemons, R. V. \& Carley, T. L. (2012). Rhyolite-MELTS: a Modified Calibration of MELTS Optimized for Silica-rich, Fluid-bearing Magmatic Systems. Journal of Petrology 53, 875-890.

Harley, S. L. \& Kelly, N. M. (2007). Zircon Tiny but Timely. Elements 3, 13-18.

Harrison, T. M. \& Watson, E. B. (1983). Kinetics of zircon dissolution and zirconium diffusion in granitic melts of variable water content. Contributions to Mineralogy and Petrology 84, 66-72. Harrison, T. M., Watson, E. B. \& Aikman, A. B. (2007). Temperature spectra of zircon crystallization in plutonic rocks. Geology 35, 635-638.

Hatch, F. H. (1908). "Kimberlite" and the Source of the Diamond in South Africa. Nature 77, 224. Hayden, L. A. \& Watson, E. B. (2007). Rutile saturation in hydrous siliceous melts and its bearing on Ti-thermometry of quartz and zircon. Earth and Planetary Science Letters 258, 561-568.

Henriksen, N., Higgins, A. K., Kalsbeek, F. \& Pulvertaft, T. C. R. (2009). Greenland from Archaean to Quaternary. Geological Survey of Denmark and Greenland Bulletin 18, 126.

Hildreth, W. \& Moorbath, S. (1988). Crustal contributions to arc magmatism in the Andes of Central Chile. Contributions to Mineralogy and Petrology 98, 455-489.

Horstwood, M. S. A., Košler, J., Gehrels, G., Jackson, S. E., McLean, N. M., Paton, C., Pearson, N. J., Sircombe, K., Sylvester, P., Vermeesch, P., Bowring, J. F., Condon, D. J. \& Schoene, B. (2016). Community-Derived Standards for LA-ICP-MS U-(Th-)Pb Geochronology - Uncertainty Propagation, Age Interpretation and Data Reporting. Geostandards and Geoanalytical Research 40, 311-332. Hoskin, P. W. O. (2000). Patterns of chaos: fractal statistics and the oscillatory chemistry of zircon. Geochimica et Cosmochimica Acta 64, 1905-1923.

Jackson, S. E., Pearson, N. J., Griffin, W. L. \& Belousova, E. A. (2004). The application of laser ablation-inductively coupled plasma-mass spectrometry to in situ U-Pb zircon geochronology. Chemical Geology 211, 47-69.

Jeon, H. \& Williams, I. S. (2018). Trace inheritance-Clarifying the zircon O-Hf isotopic fingerprint of I-type granite sources: Implications for the restite model. Chemical Geology 476, 456-468. Johnson, C. M. (1989). Isotopic zonations in silicic magma chambers. Geology 17, 1136-1139. Jourdan, F., Bertrand, H., Schärer, U., Blichert-Toft, J., Féraud, G. \& Kampunzu, A. (2007). Major and trace element and $\mathrm{Sr}, \mathrm{Nd}, \mathrm{Hf}$, and $\mathrm{Pb}$ isotope compositions of the Karoo large igneous province, Botswana-Zimbabwe: lithosphere vs mantle plume contribution. Journal of Petrology 48, 1043-1077. Kalsbeek, F., Austrheim, H., Bridgwater, D., Hansen, B. T., Pedersen, S. \& Taylor, P. N. (1993). Geochronology of Archaean and Proterozoic events in the Ammassalik area, South-East Greenland, and comparisons with the Lewisian of Scotland and the Nagssugtoqidian of West Greenland. Precambrian Research 62, 239-270.

Kelsey, D. E., Clark, C. \& Hand, M. (2008). Thermobarometric modelling of zircon and monazite growth in melt-bearing systems: Examples using model metapelitic and metapsammitic granulites. Journal of Metamorphic Geology 26, 199-212.

Kemp, A. I. S., Whitehouse, M. J., Hawkesworth, C. J. \& Alarcon, M. K. (2005). A zircon U-Pb study of metaluminous (I-type) granites of the Lachlan Fold Belt, southeastern Australia: implications for the high/low temperature classification and magma differentiation processes. Contributions to Mineralogy and Petrology 150, 230-249.

Kirkland, C. L., Smithies, R. H., Taylor, R. J. M., Evans, N. \& McDonald, B. (2015). Zircon Th/U ratios in magmatic environs. Lithos 212-215, 397-414.

Kirkland, C. L., Yakymchuk, C., Gardiner, N. J., Szilas, K., Hollis, J., Olierook, H. \& Steenfelt, A. (2020). Titanite petrochronology linked to phase equilibrium modelling constrains tectono-thermal events in the Akia Terrane, West Greenland. Chemical Geology 536, 119467. 
Kirkland, C. L., Yakymchuk, C., Hollis, J., Heide-Jørgensen, H. \& Danišík, M. (2018a). Mesoarchean exhumation of the Akia terrane and a common Neoarchean tectonothermal history for West Greenland. Precambrian Research 314, 129-144.

Kirkland, C. L., Yakymchuk, C., Szilas, K., Evans, N., Hollis, J., McDonald, B. \& Gardiner, N. J. (2018b). Apatite: a U-Pb thermochronometer or geochronometer? Lithos 318-319, 143-157.

Krogh, T. E. (1973). A low-contamination method for hydrothermal decomposition of zircon and extraction of $\mathrm{U}$ and $\mathrm{Pb}$ for isotopic age determinations. Geochimica et Cosmochimica Acta 37, 485494.

Le Bas, M. J., Le Maitre, R. W., Streckeisen, A., Zanettin, B. \& IUGS Subcommission on the Systematics of Igneous Rocks. (1986). A Chemical Classification of Volcanic Rocks Based on the Total Alkali-Silica Diagram. Journal of Petrology 27, 745-750.

Lee, C.-T. A. \& Bachmann, O. (2014). How important is the role of crystal fractionation in making intermediate magmas? Insights from Zr and P systematics. Earth and Planetary Science Letters 393, 266-274.

Lee, J. K. W., Williams, I. S. \& Ellis, D. J. (1997). Pb, U and Th diffusion in natural zircon. Nature 390, 159-162.

Liu, D., Zhao, Z., Zhu, D.-C., Niu, Y. \& Harrison, T. M. (2014). Zircon xenocrysts in Tibetan ultrapotassic magmas: Imaging the deep crust through time. Geology 42, 43-46.

Marsh, J. H., Jørgensen, T. R. C., Petrus, J. A., Hamilton, M. A. \& Mole, D. R. (2019). U-Pb, trace element, and hafnium isotope composition of the Maniitsoq zircon: A potential new Archean zircon reference material. Goldschmidt. Barcelona, 18-23 August, 2161.

Martin, H., Smithies, R. H., Rapp, R., Moyen, J. F. \& Champion, D. (2005). An overview of adakite, tonalite-trondhjemite-granodiorite (TTG), and sanukitoid: relationships and some implications for crustal evolution. Lithos 79, 1-24.

Matzel, J. E. P., Bowring, S. A. \& Miller, R. B. (2006). Time scales of pluton construction at differing crustal levels: Examples from the Mount Stuart and Tenpeak intrusions, North Cascades, Washington. GSA Bulletin 118, 1412-1430.

Middlemost, E. A. K. (1994). Naming materials in the magma/igneous rock system. Earth-Science Reviews 37, 215-224.

Miller, J. S., Matzel, J. E. P., Miller, C. F., Burgess, S. D. \& Miller, R. B. (2007). Zircon growth and recycling during the assembly of large, composite arc plutons. Journal of Volcanology and Geothermal Research 167, 282-299.

Milord, I., Sawyer, E. W. \& Brown, M. (2001). Formation of diatexite migmatite and granite magma during anatexis of semi-pelitic metasedimentary rocks: an example from St. Malo, France. Journal of Petrology 42, 487-505.

Morfin, S., Sawyer, E. W. \& Bandyayera, D. (2013). Large volumes of anatectic melt retained in granulite facies migmatites: An injection complex in northern Quebec. Lithos 168, 200-218. Morfin, S., Sawyer, E. W. \& Bandyayera, D. (2014). The geochemical signature of a felsic injection complex in the continental crust: Opinaca Subprovince, Quebec. Lithos 196-197, 339-355. Mundil, R., Ludwig, K. R., Metcalfe, I. \& Renne, P. R. (2004). Age and Timing of the Permian Mass Extinctions: U/Pb Dating of Closed-System Zircons. Science 305, 1760-1763.

Næraa, T., Kemp, A. I. S., Scherstén, A., Rehnström, E. F., Rosing, M. T. \& Whitehouse, M. J. (2014). A lower crustal mafic source for the ca. 2550Ma Qôrqut Granite Complex in southern West Greenland. Lithos 192-195, 291-304.

Nasdala, L., Kostrovitsky, S., Kennedy, A. K., Zeug, M. \& Esenkulova, S. A. (2014). Retention of radiation damage in zircon xenocrysts from kimberlites, Northern Yakutia. Lithos 206-207, 252-261. Nasdala, L., Zhang, M., Kempe, U., Panczer, G., Gaft, M., Andrut, M. \& Plötze, M. (2003). Spectroscopic methods applied to zircon. Reviews in Mineralogy and Geochemistry 53, 427-467. 
Nutman, A. P. \& Collerson, K. D. (1991). Very early Archean crustal-accretion complexes preserved in the North Atlantic craton. Geology 19, 791-794.

Olierook, H. K. H., Barham, M., Fitzsimons, I. C. W., Timms, N. E., Jiang, Q., Evans, N. J. \& McDonald, B. J. (2019). Tectonic controls on sediment provenance evolution in rift basins: Detrital zircon U-Pb and $\mathrm{Hf}$ isotope analysis from the Perth Basin, Western Australia. Gondwana Research 66, 126-142. Olierook, H. K. H., Sheppard, S., Johnson, S. P., Occhipinti, S. A., Reddy, S. M., Clark, C., Fletcher, I. R., Rasmussen, B., Zi, J.-W., Pirajno, F., LaFlamme, C., Do, T., Ware, B., Blandthorn, E., Lindsay, M., Lu, Y.J., Crossley, R. J. \& Erickson, T. M. (2018). Extensional episodes in the Paleoproterozoic Capricorn Orogen, Western Australia, revealed by petrogenesis and geochronology of mafic-ultramafic rocks. Precambrian Research 306, 22-40.

Pack, B., Schmitt, A. K., Roberge, J., Tenorio, F. G. \& Damiata, B. N. (2016). Zircon xenocryst resorption and magmatic regrowth at El Chichón Volcano, Chiapas, Mexico. Journal of Volcanology and Geothermal Research 311, 170-182.

Peterman, E. M., Reddy, S. M., Saxey, D. W., Snoeyenbos, D. R., Rickard, W. D. A., Fougerouse, D. \& Kylander-Clark, A. R. C. (2016). Nanogeochronology of discordant zircon measured by atom probe microscopy of Pb-enriched dislocation loops. Science Advances $\mathbf{2}$.

Pidgeon, R. T. \& Aftalion, M. (1978). Cogenetic and inherited zircon U-Pb systems in granites: Palaeozoic granites of Scotland and England. Geological Journal, Special Issue 10, 183-220. Polat, A., Wang, L. \& Appel, P. W. U. (2015). A review of structural patterns and melting processes in the Archean craton of West Greenland: Evidence for crustal growth at convergent plate margins as opposed to non-uniformitarian models. Tectonophysics 662, 67-94.

Roddick, J. C. \& Bevier, M. L. (1995). U $\square$ Pb dating of granites with inherited zircon: Conventional and ion microprobe results from two Paleozoic plutons, Canadian Appalachians. Chemical Geology 119, 307-329.

Rosenberg, C. L. \& Handy, M. R. (2005). Experimental deformation of partially melted granite revisited: implications for the continental crust. Journal of Metamorphic Geology 23, 19-28.

Samperton, K. M., Bell, E. A., Barboni, M., Keller, C. B. \& Schoene, B. (2017). Zircon age-temperaturecompositional spectra in plutonic rocks. Geology 45, 983-986.

Sawyer, E. W. (1987). The role of partial melting and fractional crystallization in determining discordant migmatite leucosome compositions. Journal of Petrology 28, 445-473.

Schaltegger, U. \& Davies, J. H. F. L. (2017). Petrochronology of Zircon and Baddeleyite in Igneous Rocks: Reconstructing Magmatic Processes at High Temporal Resolution. Reviews in Mineralogy and Geochemistry 83, 297-328.

Scherstén, A. \& Garde, A. A. (2013). Complete hydrothermal re-equilibration of zircon in the Maniitsoq structure, West Greenland: A 3001 Ma minimum age of impact? Meteoritics \& Planetary Science 48, 1472-1498.

Shand, S. J. (1927). Eruptive rocks: their genesis, composition, classification, and their relation to oredeposits, with a chapter on meteorites. London: Thomas Murby and Co.

Siebel, W., Schmitt, A. K., Danišík, M., Chen, F., Meier, S., Weiß, S. \& Eroğlu, S. (2009). Prolonged mantle residence of zircon xenocrysts from the western Eger rift. Nature Geoscience 2, 886.

Siégel, C., Bryan, S. E., Allen, C. M. \& Gust, D. A. (2018). Use and abuse of zircon-based thermometers: A critical review and a recommended approach to identify antecrystic zircons. EarthScience Reviews 176, 87-116.

Simon, J. I., Renne, P. R. \& Mundil, R. (2008). Implications of pre-eruptive magmatic histories of zircons for U-Pb geochronology of silicic extrusions. Earth and Planetary Science Letters 266, 182194.

Sláma, J., Košler, J., Condon, D. J., Crowley, J. L., Gerdes, A., Hanchar, J. M., Horstwood, M. S. A., Morris, G. A., Nasdala, L., Norberg, N., Schaltegger, U., Schoene, B., Tubrett, M. N. \& Whitehouse, M. 
J. (2008). Plešovice zircon - A new natural reference material for U-Pb and $\mathrm{Hf}$ isotopic microanalysis. Chemical Geology 249, 1-35.

Smithies, R. H., Howard, H. M., Kirkland, C. L., Korhonen, F. J., Medlin, C. C., Maier, W. D., de Gromard, R. Q. \& Wingate, M. T. D. (2015). Piggy-back Supervolcanoes-Long-Lived, Voluminous, Juvenile Rhyolite Volcanism in Mesoproterozoic Central Australia. Journal of Petrology 56, 735-763. Soesoo, A. (2000). Fractional crystallization of mantle-derived melts as a mechanism for some I-type granite petrogenesis: an example from Lachlan Fold Belt, Australia. Journal of the Geological Society 157, 135-149.

Solar, G. S. \& Brown, M. (2001). Petrogenesis of migmatites in Maine, USA: possible source of peraluminous leucogranite in plutons? Journal of Petrology 42, 789-823.

Speer, J. A. (1980). Zircon. In: Ribbe, P. H. (ed.) Orthosilicates, Reviews in Mineralogy. Washington, DC: Mineralogical Society of America, 67-112.

Spera, F. J. \& Bohrson, W. A. (2001). Energy-Constrained Open-System Magmatic Processes I: General Model and Energy-Constrained Assimilation and Fractional Crystallization (EC-AFC) Formulation. Journal of Petrology 42, 999-1018.

Stern, R. A., Bodorkos, S., Kamo, S. L., Hickman, A. H. \& Corfu, F. (2009). Measurement of SIMS Instrumental Mass Fractionation of Pb Isotopes During Zircon Dating. Geostandards and Geoanalytical Research 33, 145-168.

Streckeisen, A. L. (1967). Classification and nomenclature of igneous rockes. N. Jb. Miner. 107, 144240.

Sun, S.-s. \& McDonough, W. F. (1989). Chemical and isotopic systematics of oceanic basalts: implications for mantle composition and processes. Geological Society, London, Special Publications 42, 313-345.

Valley, J. W. (2003). Oxygen Isotopes in Zircon. Reviews in Mineralogy and Geochemistry 53, 343385.

Van Kranendonk, M. J. \& Kirkland, C. L. (2013). Orogenic climax of Earth: the 1.2-1.1 Ga Grenvillian superevent. Geology 41, 735-738.

Villaros, A., Stevens, G., Moyen, J.-F. \& Buick, I. S. (2009). The trace element compositions of S-type granites: evidence for disequilibrium melting and accessory phase entrainment in the source.

Contributions to Mineralogy and Petrology 158, 543-561.

Watson, E. B., Chemiak, D. J., Hanchar, J. M., Harrison, T. M. \& Wark, D. A. (1997). The incorporation of $\mathrm{Pb}$ into zircon. Chemical Geology 141, 19-31.

Watson, E. B. \& Harrison, T. M. (1983). Zircon saturation revisited: temperature and composition effects in a variety of crustal magma types. Earth and Planetary Science Letters 64, 295-304.

Watson, E. B. \& Harrison, T. M. (2005). Zircon thermometer reveals minimum melting conditions on earliest Earth. Science 308, 841-844.

Wiedenbeck, M., AllÉ, P., Corfu, F., Griffin, W. L., Meier, M., Oberli, F., Quadt, A. V., Roddick, J. C. \& Spiegel, W. (1995). Three natural zircon standards For U-Th-Pb, Lu-Hf, trace element And REE analyses. Geostandards Newsletter 19, 1-23.

Windley, B. F. \& Garde, A. A. (2009). Arc-generated blocks with crustal sections in the North Atlantic craton of West Greenland: Crustal growth in the Archean with modern analogues. Earth-Science Reviews 93, 1-30.

Wotzlaw, J.-F., Schaltegger, U., Frick, D. A., Dungan, M. A., Gerdes, A. \& Günther, D. (2013). Tracking the evolution of large-volume silicic magma reservoirs from assembly to supereruption. Geology 41, 867-870.

Wu, F., Liu, X., Ji, W., Wang, J. \& Yang, L. (2017). Highly fractionated granites: Recognition and research. Science China Earth Sciences 60, 1201-1219.

Yakymchuk, C. (2019). On Granites. Journal of the Geological Society of India 94, 9-22. 
Yakymchuk, C. \& Brown, M. (2014). Behaviour of zircon and monazite during crustal melting. Journal of the Geological Society 171, 465-479.

Yakymchuk, C., Brown, M., Ivanic, T. J. \& Korhonen, F. J. (2013). Leucosome distribution in migmatitic paragneisses and orthogneisses: A record of self-organized melt migration and entrapment in a heterogeneous partially-molten crust. Tectonophysics 603, 136-154.

Yakymchuk, C., Kirkland, C. L., Hollis, J. A., Kendrick, J., Gardiner, N. J. \& Szilas, K. (2020).

Mesoarchean partial melting of mafic crust and tonalite production during high-T-low-P stagnant tectonism, Akia Terrane, West Greenland. Precambrian Research, 105615.

Zen, E. A. (1986). Aluminum Enrichment in Silicate Melts by Fractional Crystallization: Some

Mineralogic and Petrographic Constraints. Journal of Petrology 27, 1095-1117.

\section{Figure captions}

Fig. 1: Schematic image of zircon types in a magmatic plumbing system, modified from Miller $e t$ al. (2007). MASH = melting, assimilation, storage and homogenization (Hildreth \& Moorbath, 1988)

Fig. 2: Simplified geological map of the Akia Terrane, modified from Gardiner et al. (2019b), with sampling locality region labelled.

Fig. 3: Field photographs showing the cross-cutting relationships at both localities. Samples numbers are indicated in ellipses.

Fig. 4: Representative thin section photomicrographs of $(a, b)$ trondhjemite, $(c, d)$ granodiorite, and $(\mathrm{e}, \mathrm{f})$ granite $. \mathrm{xpl}=$ transmitted, cross-polarized light, $\mathrm{TIMA}=$ automated mineral analysis image taken using Tescan Automated Mineral Analyzer. Insets in e-f show zircon grain entombed in plagioclase crystal. Insets are $\sim 200 \times 150 \mu \mathrm{m}$. High-resolution, full thin section photomicrographs in transmitted plane- and cross-polarized light, and TIMA images may be found in Supplementary Fig. A. 
Fig. 5: Petrographic and whole-rock geochemical classification of granitoid samples.. Quartz-alkali feldspar (A)-plagioclase (P) classification diagram (Streckeisen, 1967). (b) Anorthite (An)-albite (Ab)-orthoclase (Or) diagram (Barker, 1979). (c) Total alkali (weight $\mathrm{Na}_{2} \mathrm{O}+\mathrm{K}_{2} \mathrm{O}$ ) vs silica (weight $\mathrm{SiO}_{2}$ ) diagram for intrusive rocks (Le Bas et al., 1986, Middlemost, 1994). (d) Aluminium saturation index: molar $\mathrm{Al}_{2} \mathrm{O}_{3} /\left(\mathrm{Na}_{2} \mathrm{O}+\mathrm{K}_{2} \mathrm{O}\right)$ vs molar $\mathrm{Al}_{2} \mathrm{O}_{3} /\left(\mathrm{CaO}+\mathrm{Na}_{2} \mathrm{O}+\mathrm{K}_{2} \mathrm{O}\right)$ (Shand, 1927, Zen, 1986).

Fig. 6: Harker diagram plots of selected major and trace element (ratios) versus $\mathrm{SiO}_{2}$, including published data from mafic amphibolites, andesite and TTGs from the Akia Terrane (Garde, 2007, Gardiner et al., 2019b, Yakymchuk et al., 2020). Rhyolite-MELTS v1.0.2 modeling (Gualda et al., 2012) curves shown for $\mathrm{MgO}$ against major elements, using (for scenario 1, see discussion): (i) sample 725 from Yakymchuk et al. (2020) as a starting composition, (ii) constant pressure $=3 \mathrm{kbar}$, adiabatic cooling from 950 to $750{ }^{\circ} \mathrm{C}$, (iii) $0.5-2.0$ wt. $\% \mathrm{H}_{2} \mathrm{O}$ concentration, (iv) a quartz-fayalitemagnetite buffer. Insets in $\mathrm{TiO}_{2}$ and $\mathrm{CaO}$ vs $\mathrm{MgO}$ relate to scenario 3 and are zoom-ins of the same MELTS model. Numbers in insets represent fractionation amounts in \% starting from the most primitive granodiorite sample (872). Note $\mathrm{SiO}_{2}$ curve is not shown due to quartz buffer, and therefore quartz cannot fractionate. Chondrite-normalization (cn) after Sun and McDonough (1989).

Fig. 7: Rare earth element and incompatible element spider diagrams. Chondrite and primitive mantle normalization) after Sun and McDonough (1989).

Fig. 8: Representative CL images of zircon grains. All images are shown at the same scale, and were taken at the same operating conditions. Dashed circles and adjacent numbers correspond to $30 \mu \mathrm{m}$ 
laser ablation spots. A full compendium of all zircon CL images may be found in Supplementary Fig. B.

Fig. 9: Tera-Wasserburg U-Pb inverse concordia plots for zircon sorted by sample. (a-c) trondhjemite (squares). (d-e) granodiorite (circles). (f) granite (diamonds). Colors correspond to interpretations based on morphological analysis, CL response and zircon trace element data (see Table 3). Note that a single highly discordant analysis from sample 1417 is not shown due to clarity. Full U-Pb data tables may be found in Supplementary Table B.

Fig. 10: Tera-Wasserburg U-Pb inverse concordia plots for zircon sorted by textural grouping. (a) Group 1. (b) Group 2. (c) Group 3. (d) Group 4. (e) Group 5. For interpretation to autocrystic and inherited grains, see discussion section 6.1. Full U-Pb data tables may be found in Supplementary Table B.

Fig. 11: Box-and-whisker plots for selected zircon U-Pb dates and trace elements in texturallyclassified groups.

Fig. 12: Th/U tool for the identification of autocrystic, antecrystic and other inherited zircon grains. Kirkland and Siegel figure. (a) Fractionation factor, defined by $\mathrm{Th}_{\text {(zircon/rock) }} / \mathrm{U}_{\text {(zircon/rock) }}$ versus $\mathrm{T}_{\text {ZircTi }}$, with method from Kirkland et al. (2015). Autocrysts should plot along a fractionation trend below the equilibrium crystallization curve and antecrysts should plot above the curve. (b) Method for the 
identification of xenocrystic and restitic zircon grains, showing notable differences to the field of autocrystic grains defined in (a).

Fig. 13: Schematic illustration of the sequential formation of trondhjemite, granodiorite and high silica granite in the Akia Terrane from similarly hydrated mafic amphibolite sources, with their incorporation of different types of zircon. (a) Formation of trondhjemite at ca. $3010 \mathrm{Ma}$ with autocrystic (1) and restitic (4) zircon grains. (b) Formation of granodiorite at ca. 2975 Ma with autocrystic (2 and 3), xenocrystic (1 from trondhjemite) and restitic (4) zircon grains. (c) Formation of granite after ca. 2975 Ma with xenocrystic (1 from trondhjemite, and $2 \& 3$ from granodiorite) and restitic (4) zircon grains.

Table 1: Locations and petrographic descriptions/modal abundances. Modal abundances are from automated mineralogy data on the entire thin section.

Table 2: Whole-rock geochemistry for new samples from the Akia Terrane.

Table 3: Classification of zircon fractions using grain habit, internal textures, trace element concentrations and $\mathrm{U}-\mathrm{Pb}$ dates.

Supplementary Table A: Full whole-rock geochemical data, including quality control information 
Supplementary Table B: Full zircon U-Pb and trace element data

Supplementary Fig. A: Full thin section photomicrographs of all samples in: (i) transmitted, planepolarized light, (ii) cross-polarized light, and (iii) automated mineral analysis images.

Supplementary Fig. B: Panoramas of zircon internal textures in CL. 


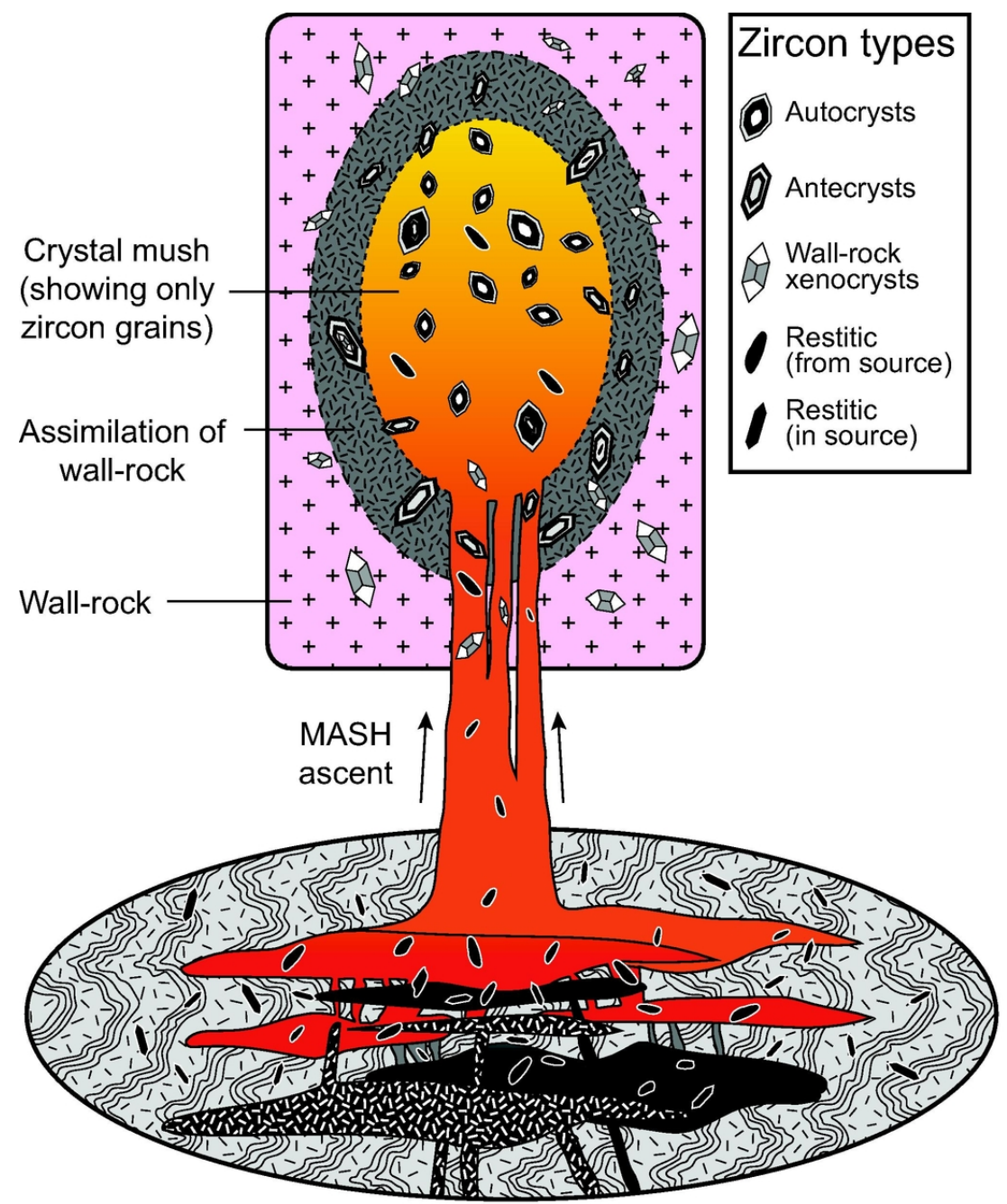

Deep crustal zone of mafic input, partial melting and mixing ('MASH')

\section{Olierook et al., Figure 1}

Fig. 1: Schematic image of zircon types in a magmatic plumbing system, modified from Miller et al. (2007). $\mathrm{MASH}=$ melting, assimilation, storage and homogenization (Hildreth \& Moorbath, 1988)

$87 \times 124 \mathrm{~mm}(300 \times 300 \mathrm{DPI})$ 


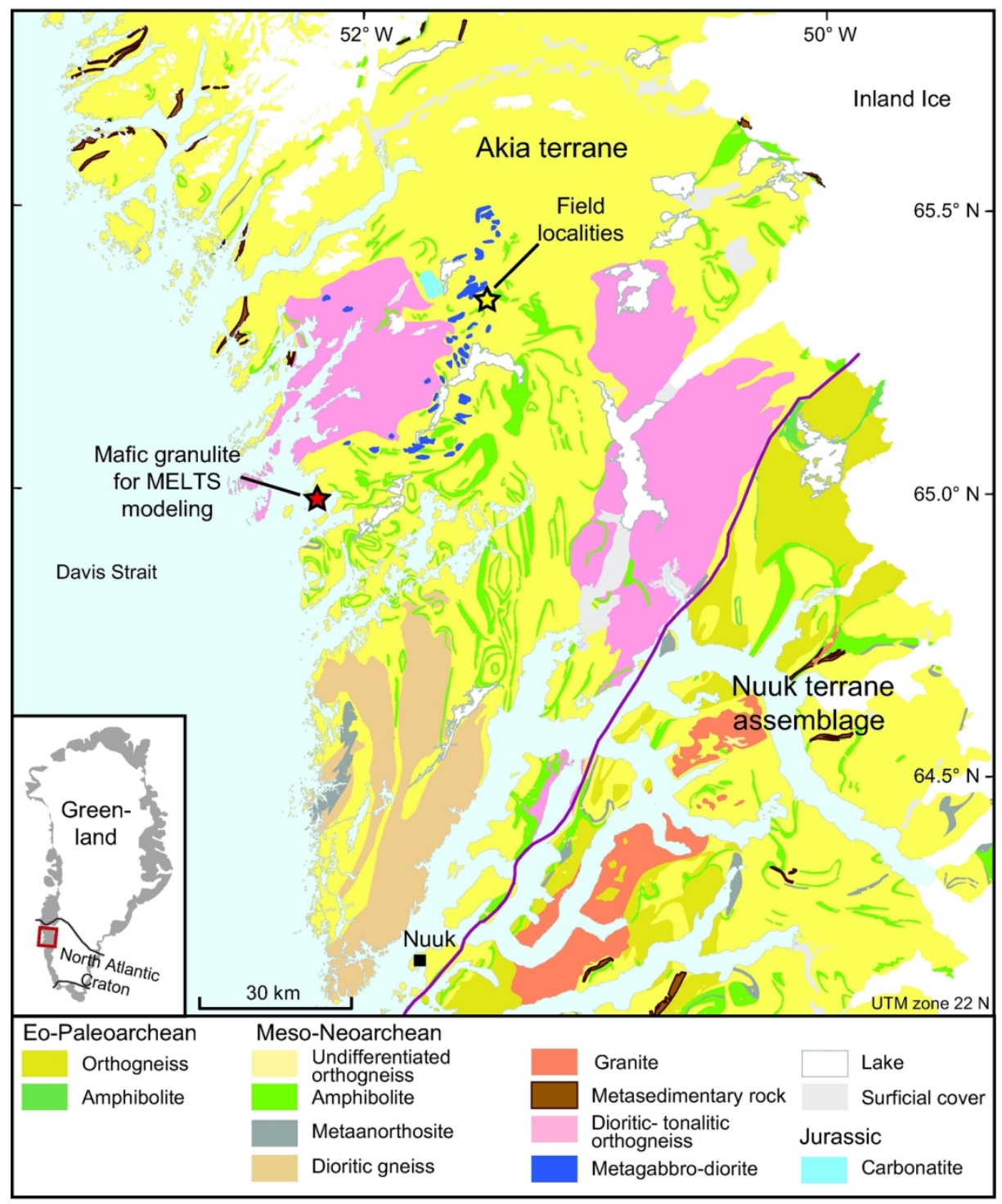

\section{Olierook et al., Figure 2}

Fig. 2: Simplified geological map of the Akia Terrane, modified from Gardiner et al. (2019b), with sampling locality region labelled.

$123 \times 159 \mathrm{~mm}(300 \times 300 \mathrm{DPI})$ 

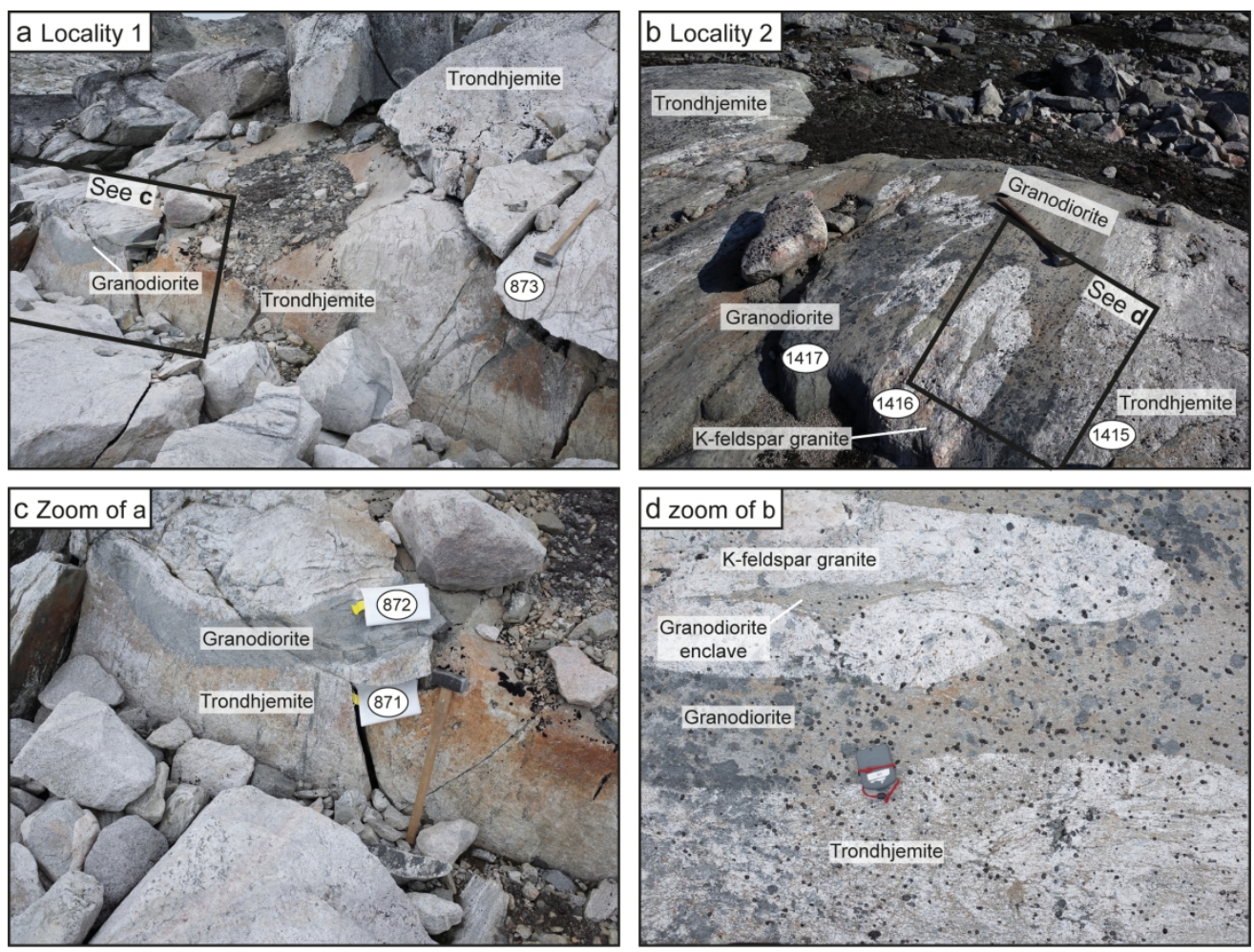

Olierook et al., Figure 3

Fig. 3: Field photographs showing the cross-cutting relationships at both localities. Samples numbers are indicated in ellipses.

$179 \times 146 \mathrm{~mm}(300 \times 300 \mathrm{DPI})$ 


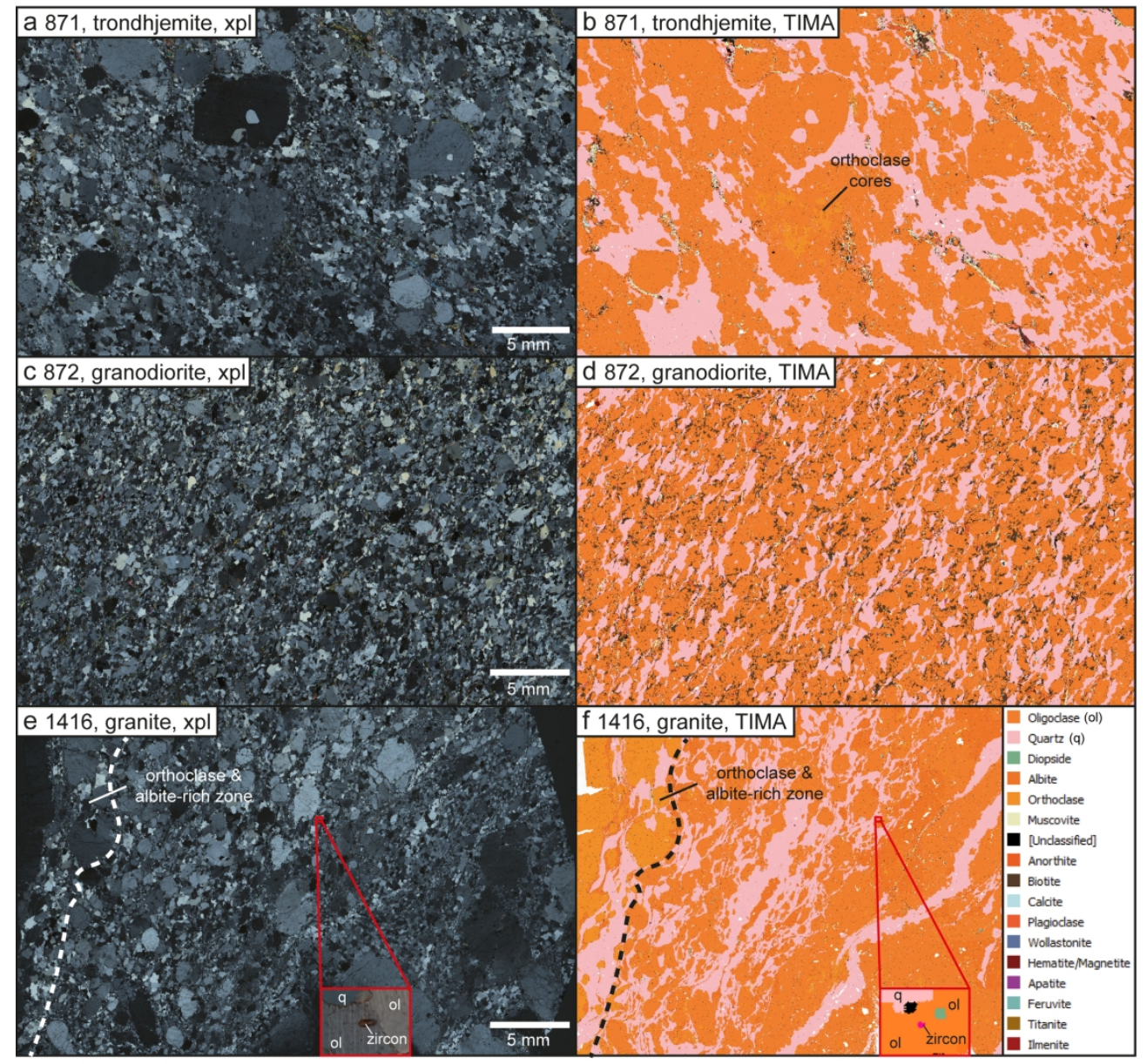

Olierook et al., Figure 4

Fig. 4: Representative thin section photomicrographs of $(a, b)$ trondhjemite, $(c, d)$ granodiorite, and (e,f) granite. $\mathrm{xpl}=$ transmitted, cross-polarized light, TIMA = automated mineral analysis image taken using Tescan Automated Mineral Analyzer. Insets in e-f show zircon grain entombed in plagioclase crystal. Insets are $\sim 200 \times 150 \mu \mathrm{m}$. High-resolution, full thin section photomicrographs in transmitted plane- and crosspolarized light, and TIMA images may be found in Supplementary Fig. A.

$184 \times 196 \mathrm{~mm}(300 \times 300 \mathrm{DPI})$ 


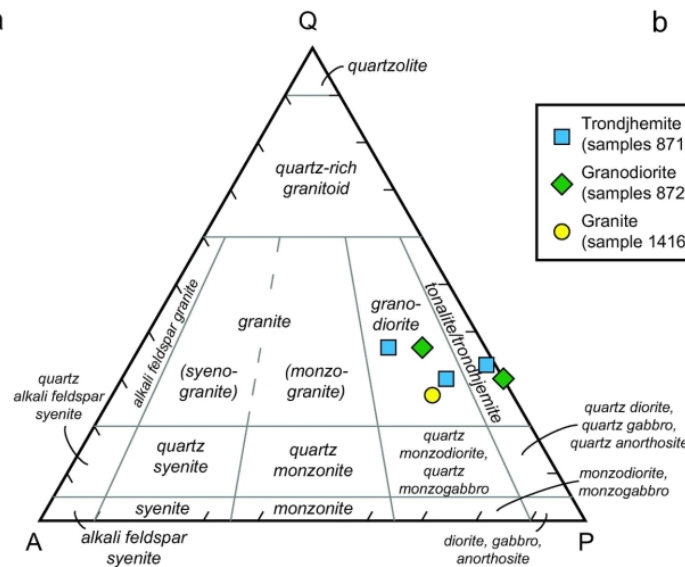

An

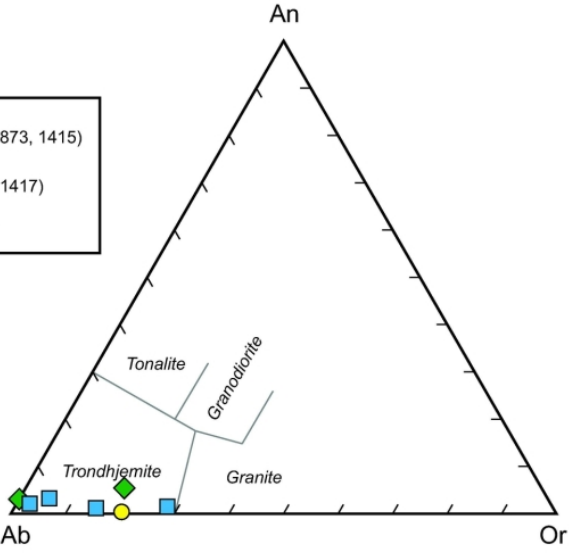

C

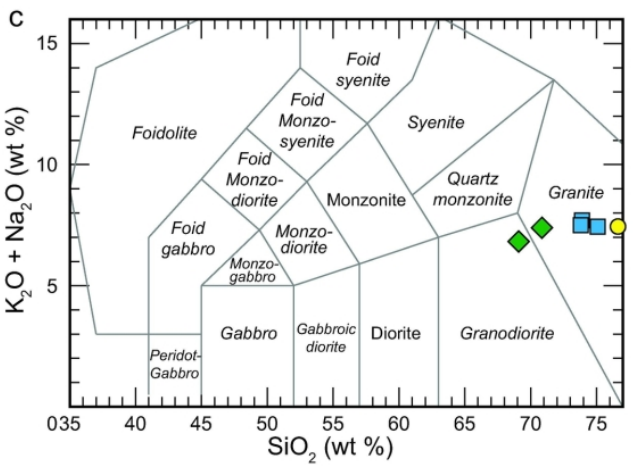

Fig. 5: Petrographic and whole-rock geochemical classification of granitoid samples.. Quartz-alkali feldspar (A)-plagioclase (P) classification diagram (Streckeisen, 1967). (b) Anorthite (An)-albite (Ab)-orthoclase (Or) diagram (Barker, 1979). (c) Total alkali (weight Na2O + K2O) vs silica (weight SiO2) diagram for intrusive rocks (Le Bas et al., 1986, Middlemost, 1994). (d) Aluminium saturation index: molar Al2O3/(Na2O+K2O) vs molar Al2O3/(CaO+Na2O+K2O) (Shand, 1927, Zen, 1986). 

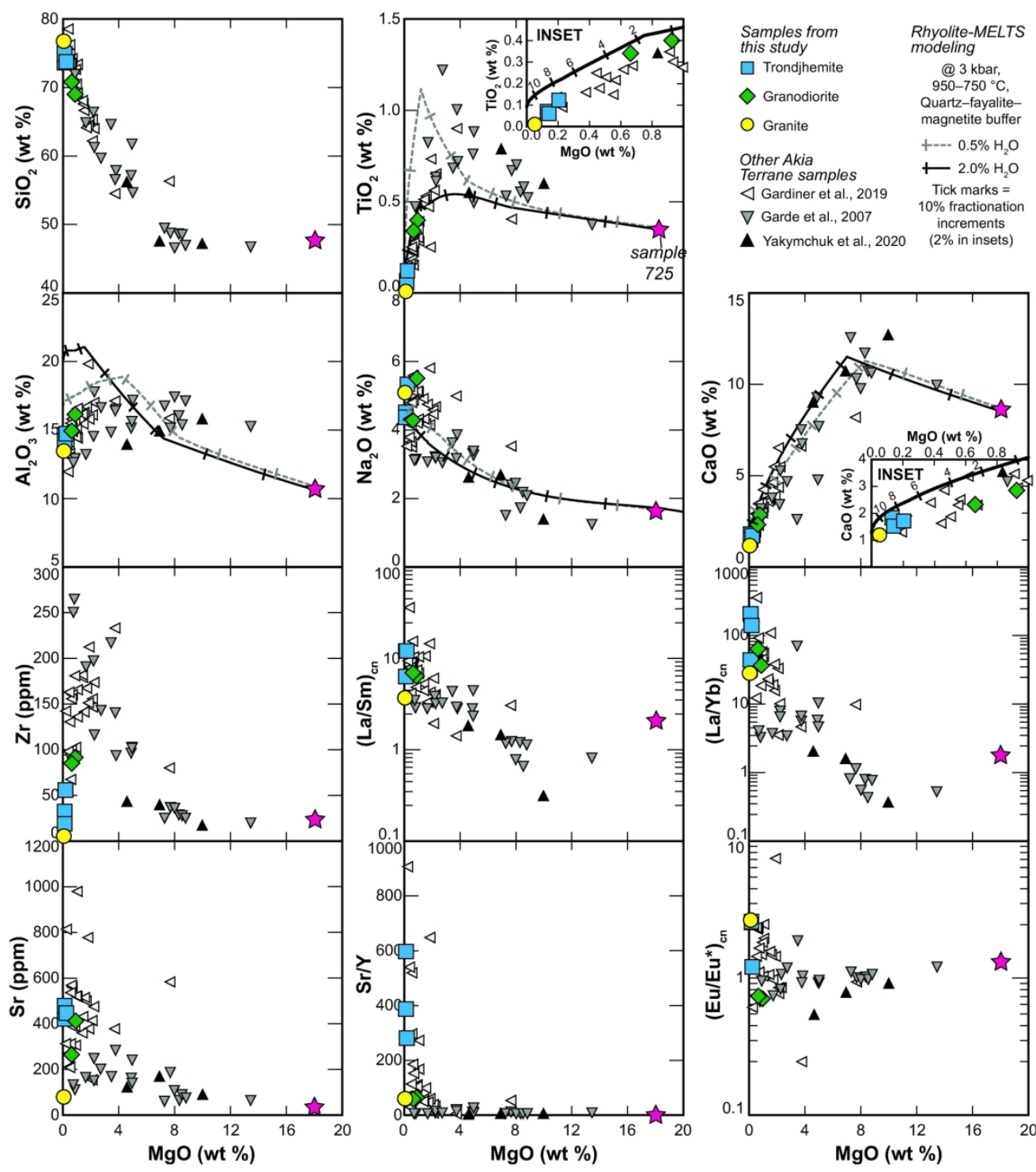

Fig. 6: Harker diagram plots of selected major and trace element (ratios) versus SiO2, including published data from mafic amphibolites, andesite and TTGs from the Akia Terrane (Garde, 2007, Gardiner et al., 2019b, Yakymchuk et al., 2020). Rhyolite-MELTS v1.0.2 modeling (Gualda et al., 2012) curves shown for $\mathrm{MgO}$ against major elements, using (for scenario 1, see discussion): (i) sample 725 from Yakymchuk et al. (2020) as a starting composition, (ii) constant pressure $=3 \mathrm{kbar}$, adiabatic cooling from 950 to $750{ }^{\circ} \mathrm{C}$, (iii) $0.5-2.0 \% \mathrm{H} 2 \mathrm{O}$ concentration, (iv) a quartz-fayalite-magnetite buffer. Insets in $\mathrm{TiO} 2$ and $\mathrm{CaO}$ vs $\mathrm{MgO}$ relate to scenario 3 and are zoom-ins of the same MELTS model. Numbers in insets represent fractionation amounts in \% starting from the most primitive granodiorite sample (872). Note SiO2 curve is not shown due to quartz buffer, and therefore quartz cannot fractionate. Chondrite-normalization (cn) after Sun and McDonough (1989). 

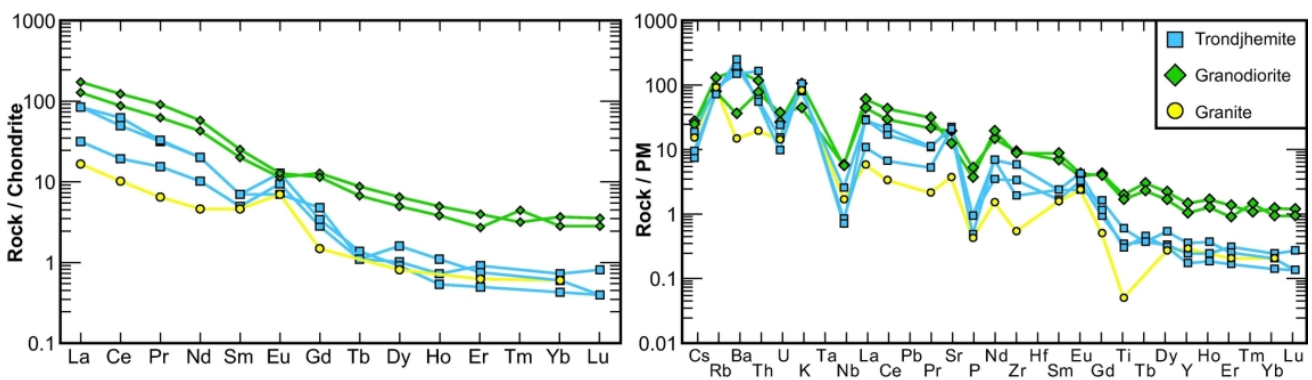

Olierook et al., Figure 7

Fig. 7: Rare earth element and incompatible element spider diagrams. Chondrite and primitive mantle normalization) after Sun and McDonough (1989).

$183 \times 66 \mathrm{~mm}(300 \times 300 \mathrm{DPI})$ 


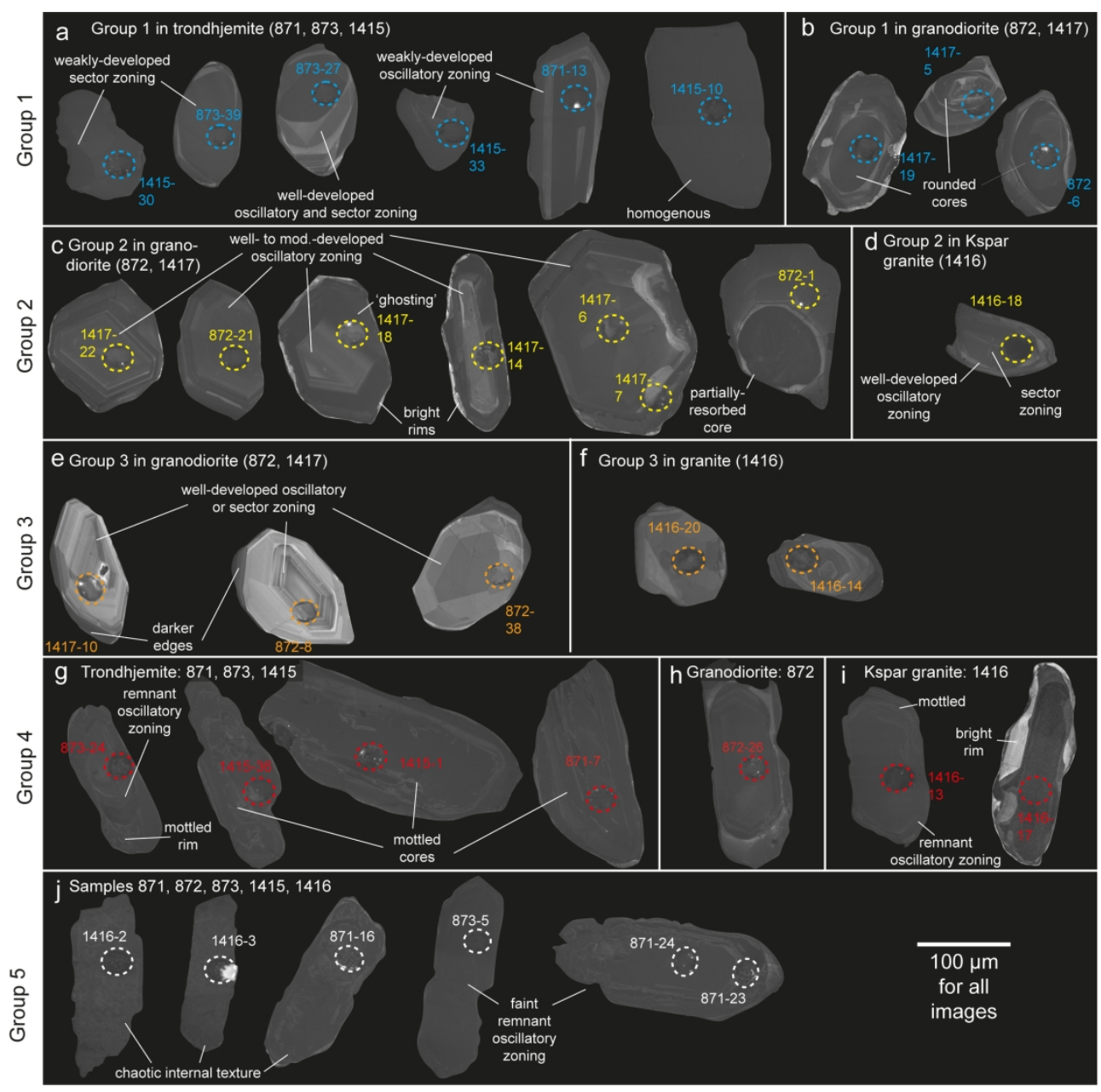

Olierook et al., Figure 8

Fig. 8: Representative $C L$ images of zircon grains. All images are shown at the same scale, and were taken at the same operating conditions. Dashed circles and adjacent numbers correspond to $30 \mu \mathrm{m}$ laser ablation spots. A full compendium of all zircon CL images may be found in Supplementary Fig. B.

$$
189 \times 192 \mathrm{~mm}(300 \times 300 \text { DPI })
$$



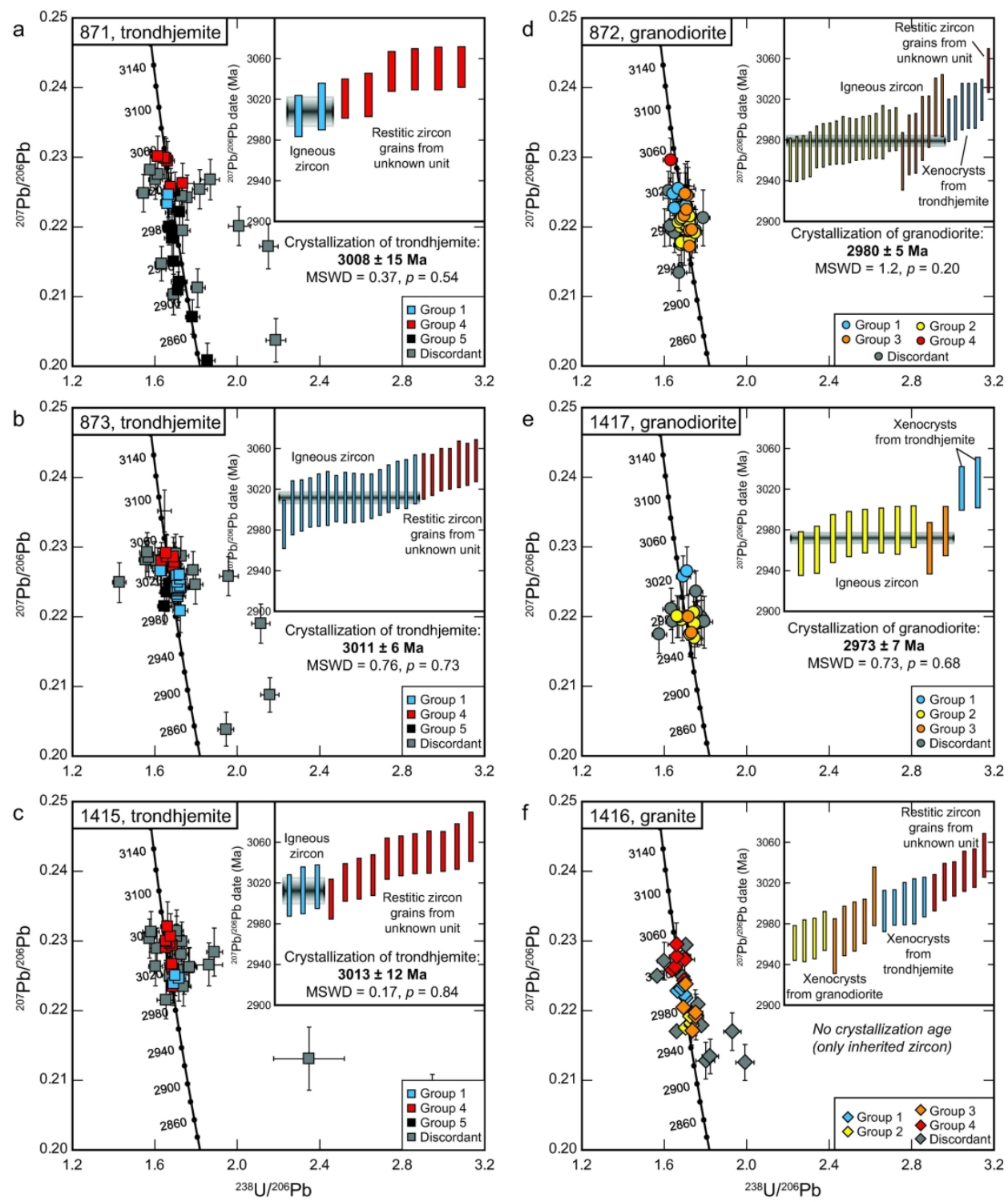

Olierook et al., Figure 9

Fig. 9: Tera-Wasserburg U-Pb inverse concordia plots for zircon sorted by sample. (a-c) trondhjemite (squares). (d-e) granodiorite (circles). (f) granite (diamonds). Colors correspond to interpretations based on morphological analysis, $\mathrm{CL}$ response and zircon trace element data (see Table 3). Note that a single highly discordant analysis from sample 1417 is not shown due to clarity. Full U-Pb data tables may be found in Supplementary Table B. 

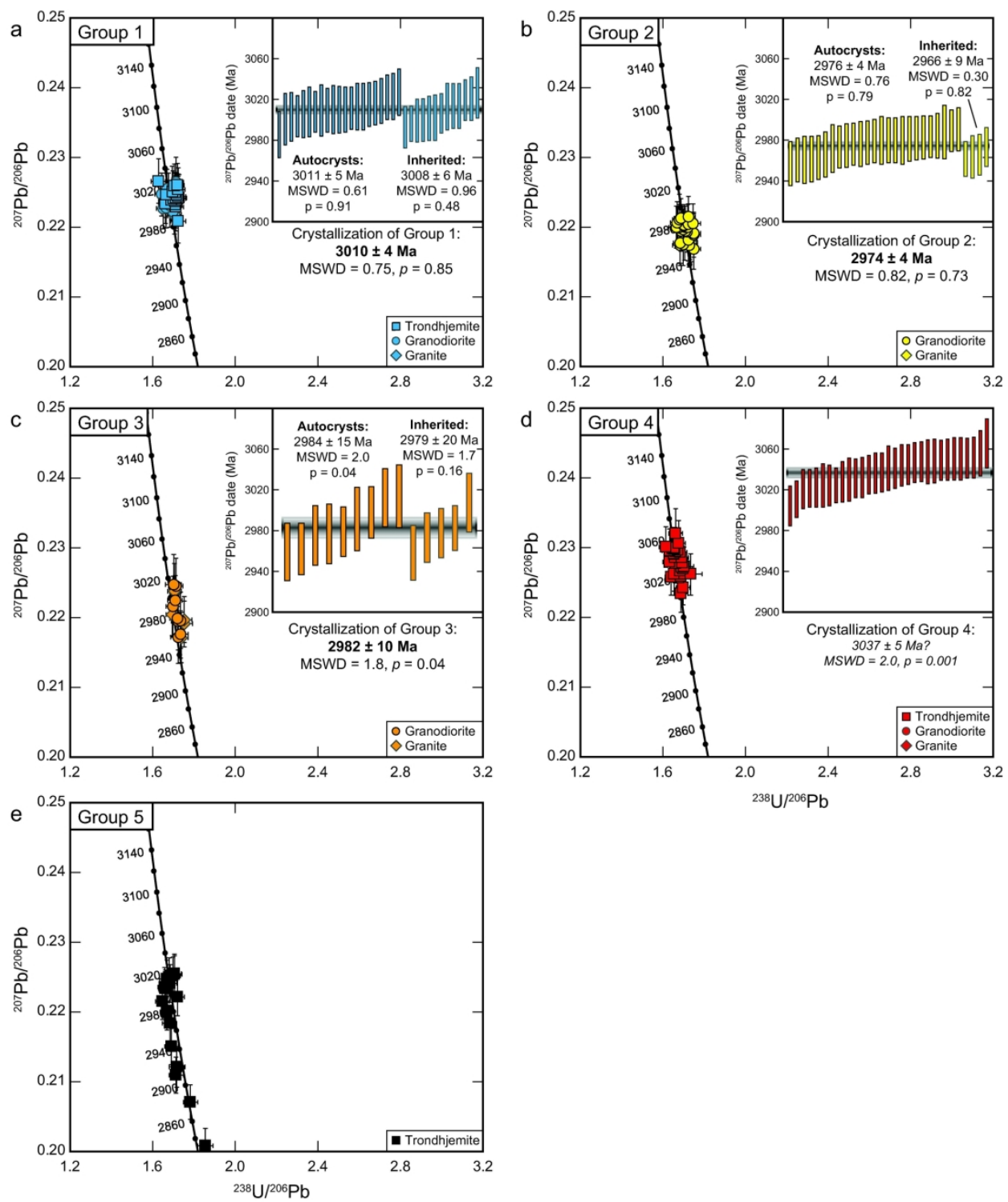

Olierook et al., Figure 10

Fig. 10: Tera-Wasserburg U-Pb inverse concordia plots for zircon sorted by textural grouping. (a) Group 1. (b) Group 2. (c) Group 3. (d) Group 4. (e) Group 5. For interpretation to autocrystic and inherited grains, see discussion section 6.1. Full U-Pb data tables may be found in Supplementary Table B. 

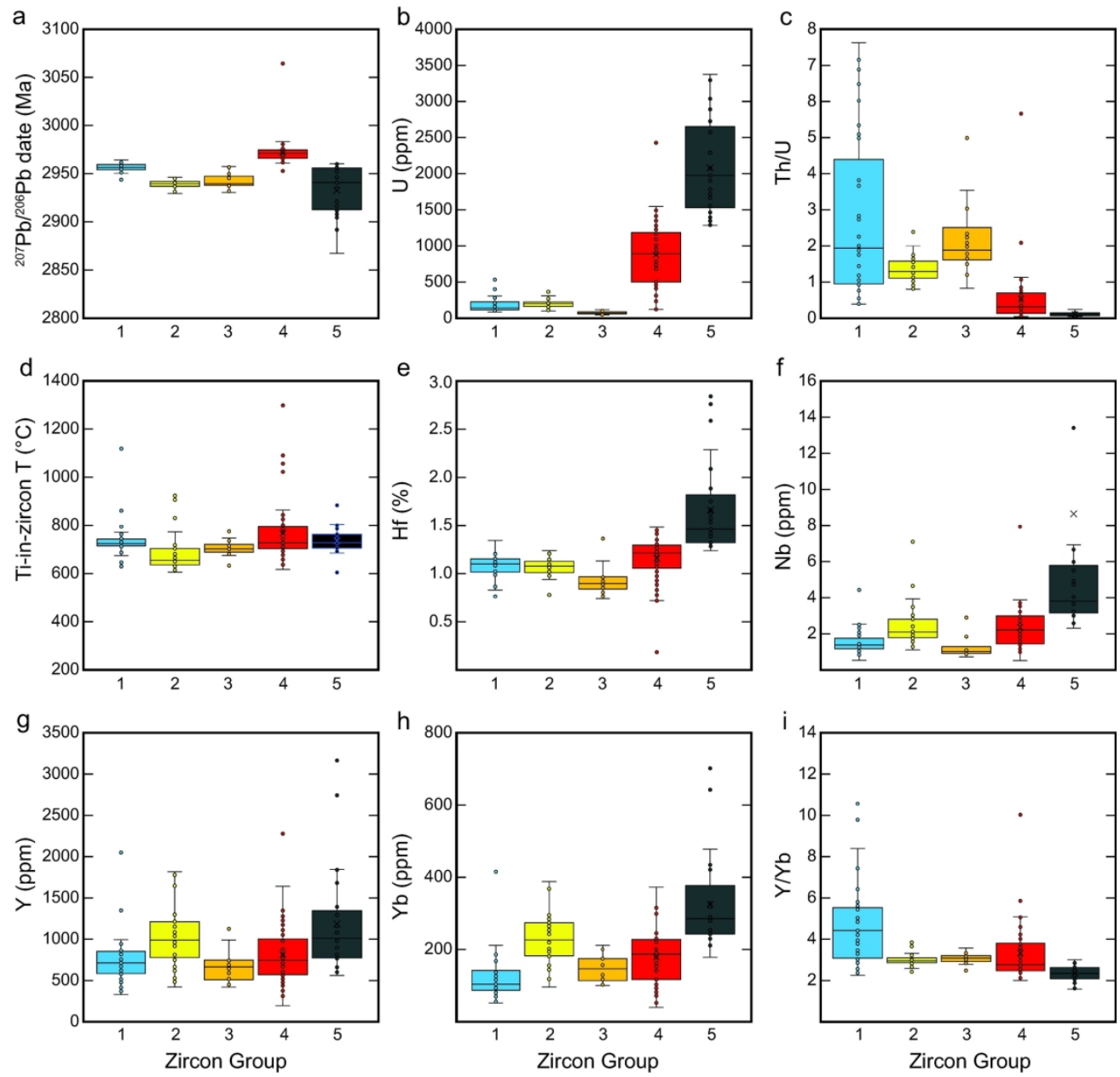

Olierook et al., Figure 11

Fig. 11: Box-and-whisker plots for selected zircon U-Pb dates and trace elements in texturally-classified groups.

$187 \times 187 \mathrm{~mm}(300 \times 300$ DPI $)$ 

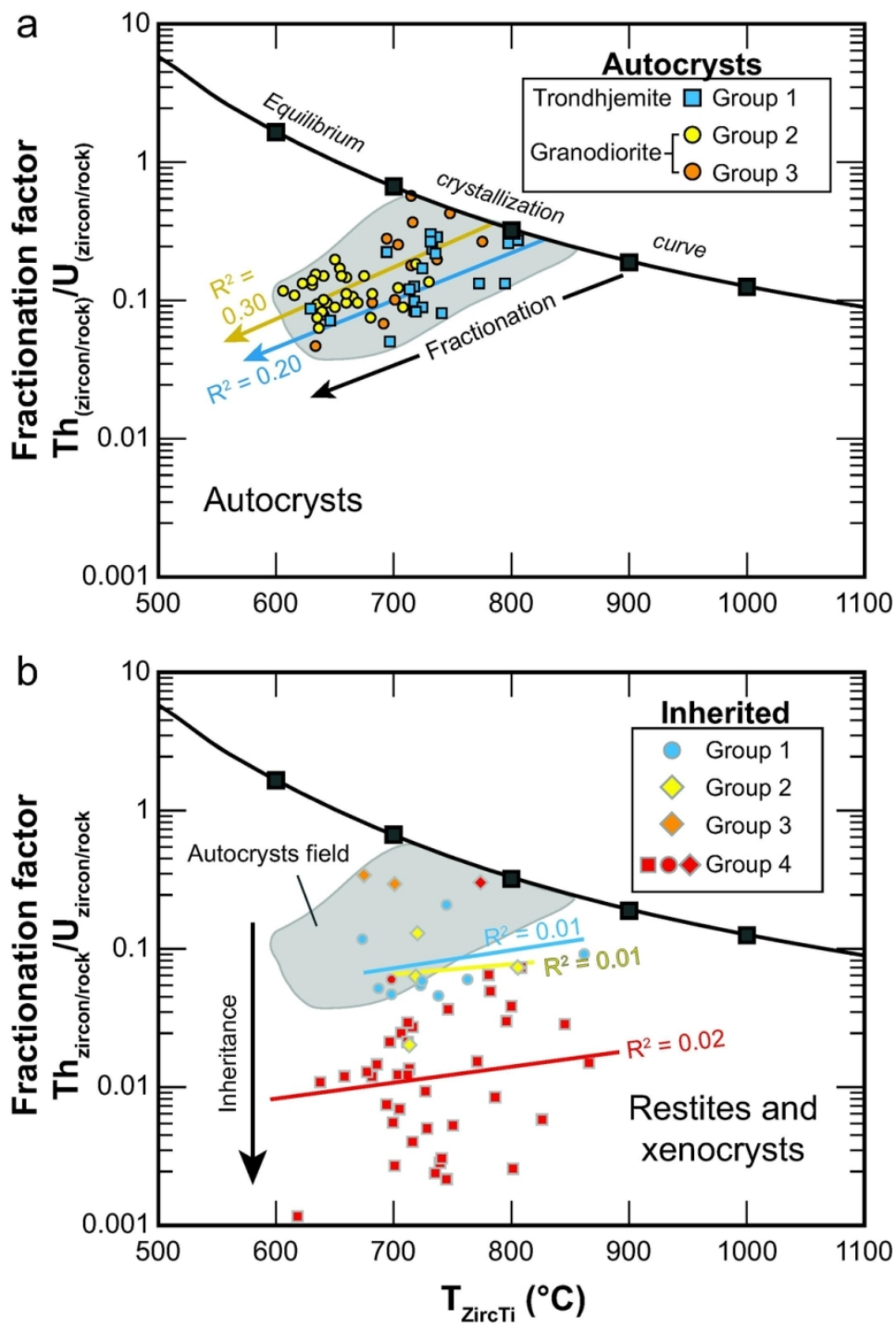

\section{Olierook et al., Figure 12}

Fig. 12: Th/U tool for the identification of autocrystic, antecrystic and other inherited zircon grains. Kirkland and Siegel figure. (a) Fractionation factor, defined by Th(zircon/rock)/U(zircon/rock) versus TZircTi, with method from Kirkland et al. (2015). Autocrysts should plot along a fractionation trend below the equilibrium crystallization curve and antecrysts should plot above the curve. (b) Method for the identification of xenocrystic and restitic zircon grains, showing notable differences to the field of autocrystic grains defined in

(a).

$91 \times 148 \mathrm{~mm}(300 \times 300 \mathrm{DPI})$ 


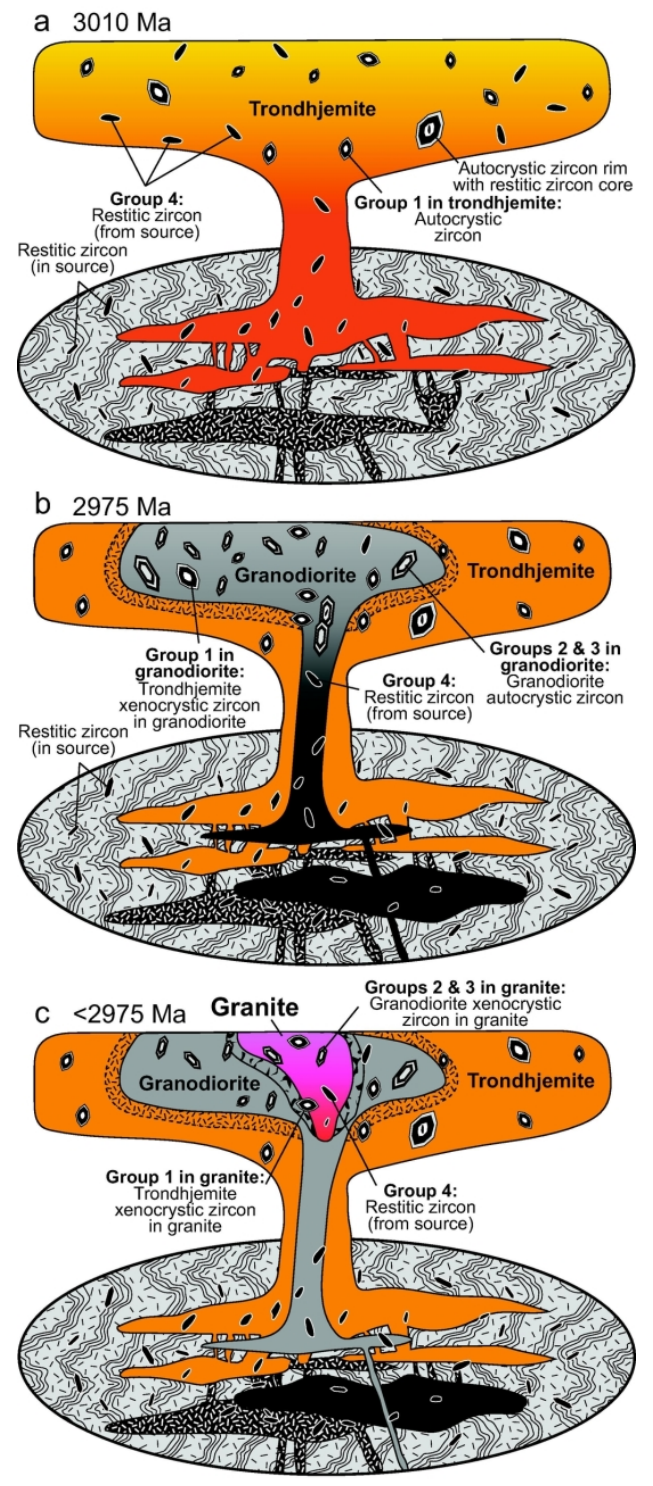

Olierook et al., Figure 13

Fig. 13: Schematic illustration of the sequential formation of trondhjemite, granodiorite and high silica granite in the Akia Terrane from similarly hydrated mafic amphibolite sources, with their incorporation of different types of zircon. (a) Formation of trondhjemite at ca. 3010 Ma with autocrystic (1) and restitic (4) zircon grains. (b) Formation of granodiorite at ca. 2975 Ma with autocrystic ( 2 and 3), xenocrystic (1 from trondhjemite) and restitic (4) zircon grains. (c) Formation of granite after ca. $2975 \mathrm{Ma}$ with xenocrystic (1 from trondhjemite, and $2 \& 3$ from granodiorite) and restitic (4) zircon grains. 


\begin{tabular}{|c|c|c|c|c|c|c|}
\hline Sample & $871^{*}$ & $873^{*}$ & 1415 & $872^{*}$ & 1417 & 1416 \\
\hline Latitude & 65.35283 & 65.35283 & 65.35283 & 65.35283 & 65.35283 & 65.35283 \\
\hline Longitude & -51.44170 & -51.44170 & -51.44106 & -51.44170 & -51.44106 & -51.44106 \\
\hline Lithology & $\begin{array}{c}\text { Trondhjemit } \\
\mathrm{e}\end{array}$ & $\begin{array}{c}\text { Trondhjemit } \\
\mathrm{e}\end{array}$ & $\begin{array}{c}\text { Trondhjemit } \\
\mathrm{e}\end{array}$ & Granodiorite & $\begin{array}{c}\text { Granodiorit } \\
\mathrm{e}\end{array}$ & $\begin{array}{l}\text { K-feldspar } \\
\text { rich } \\
\text { trondhjemite }\end{array}$ \\
\hline Quartz & 32 & 34 & 28 & 26 & 32 & 26 \\
\hline Orthoclase & 1.6 & 16 & 9.8 & 0.02 & 10 & 15 \\
\hline Albite & 2.2 & 13 & 6.9 & 2.1 & 9.3 & 18 \\
\hline Oligoclase & 59 & 29 & 48 & 57 & 33 & 39 \\
\hline Anorthite & 1.4 & 0.90 & 0.74 & 1.9 & 2.9 & 0.25 \\
\hline Muscovite & 1.7 & 3.9 & 1.7 & 1.5 & 2.3 & 0.40 \\
\hline Biotite & 0.84 & 0.89 & 1.8 & 9.0 & 4.9 & 0.00 \\
\hline Calcite & 0.37 & 0.10 & 0.00 & 0.03 & 0.00 & 0.00 \\
\hline Apatite & 0.02 & 0.01 & 0.02 & 0.18 & 0.14 & 0.00 \\
\hline Magnetite & 0.03 & 0.15 & 0.09 & 0.02 & 0.62 & 0.01 \\
\hline IImenite & 0.01 & 0.00 & 0.01 & 0.00 & 0.08 & 0.00 \\
\hline Titanite & 0.02 & 0.00 & 0.00 & 0.12 & 0.54 & 0.00 \\
\hline Zircon & 0.01 & 0.01 & 0.01 & 0.01 & 0.02 & 0.00 \\
\hline Allanite-(La) & 0.01 & 0.01 & 0.05 & 0.07 & 0.09 & 0.00 \\
\hline Unclassified & 1.5 & 2.3 & 2.4 & 2.4 & 4.4 & 1.1 \\
\hline
\end{tabular}

*Samples were taken from the same location as location 8 in Garde et al. (2012) 


\begin{tabular}{|c|c|c|c|c|c|c|}
\hline $\begin{array}{l}\text { Rock } \\
\text { Type } \\
\text { SAMPLE }\end{array}$ & $\begin{array}{c}\text { Trondhjemite } \\
871 \\
\end{array}$ & $\begin{array}{c}\text { Trondhjemite } \\
873 \\
\end{array}$ & $\begin{array}{c}\text { Trondhjemite } \\
1415 \\
\end{array}$ & $\begin{array}{c}\text { Granodiorite } \\
872 \\
\end{array}$ & $\begin{array}{c}\text { Granodiorite } \\
1417 \\
\end{array}$ & $\begin{array}{c}\text { K-feldspar } \\
\text { rich granite } \\
1416 \\
\end{array}$ \\
\hline SiO2 (\%) & 73.9 & 75.2 & 74.0 & 69.1 & 70.9 & 76.8 \\
\hline $\mathrm{Al} 2 \mathrm{O} 3(\%)$ & 14.7 & 14.2 & 14.8 & 16.2 & 15.0 & 13.5 \\
\hline Fe2O3 (\%) & 1.20 & 0.82 & 1.07 & 2.92 & 2.65 & 0.62 \\
\hline MgO (\%) & 0.13 & 0.14 & 0.20 & 0.92 & 0.66 & 0.05 \\
\hline $\mathrm{CaO}(\%)$ & 1.81 & 1.51 & 1.70 & 2.84 & 2.31 & 1.19 \\
\hline $\mathrm{Na2O}(\%)$ & 4.5 & 4.4 & 5.4 & 5.5 & 4.3 & 5.1 \\
\hline K2O (\%) & 2.99 & 3.06 & 2.34 & 1.32 & 3.12 & 2.42 \\
\hline TiO2 (\%) & 0.07 & 0.06 & 0.12 & 0.40 & 0.34 & 0.01 \\
\hline P2O5 (\%) & 0.02 & 0.02 & 0.01 & 0.11 & 0.08 & 0.01 \\
\hline MnO (\%) & 0.01 & 0.01 & 0.01 & 0.04 & 0.03 & $<0.01$ \\
\hline LOI (\%) & 0.64 & 0.57 & 0.41 & 0.69 & 0.64 & 0.27 \\
\hline Total (\%) & 100 & 100 & 100 & 100 & 100 & 100 \\
\hline Li (ppm) & 8.8 & 10.1 & 9.8 & 29.6 & 19 & 2.8 \\
\hline $\mathrm{Be}(\mathrm{ppm})$ & 0.72 & 0.42 & 0.61 & 1.06 & 1.07 & 2.29 \\
\hline Sc (ppm) & 0.8 & 0.7 & 1.2 & 4.2 & 3.2 & $<10$ \\
\hline $\mathbf{V}(\mathbf{p p m})$ & 17 & 11 & 7 & 41 & 22 & $<10$ \\
\hline $\mathrm{Cr}(\mathrm{ppm})$ & 11 & 12 & 10 & 12 & 8 & 213 \\
\hline Co (ppm) & 1.5 & 1 & 1.3 & 6.4 & 4.2 & 0.6 \\
\hline $\mathrm{Ni}(p p m)$ & 2 & 1.5 & 2.1 & 5 & 3.4 & 4.4 \\
\hline $\mathrm{Cu}$ (ppm) & 5.4 & 2.9 & 1.8 & 1.8 & 0.5 & 3.7 \\
\hline Zn (ppm) & 17 & 15 & 21 & 70 & 48 & 3 \\
\hline Ga (ppm) & 17.6 & 16.1 & 17.9 & 21.4 & 19.5 & 23.6 \\
\hline Ge (ppm) & 0.34 & 0.33 & 0.05 & 0.37 & 0.35 & 1.24 \\
\hline As (ppm) & $<0.2$ & 1.6 & $<0.2$ & 1.4 & 0.7 & 0.9 \\
\hline Se (ppm) & $<1$ & $<1$ & $<1$ & $<1$ & $<1$ & $<0.5$ \\
\hline Rb (ppm) & 52.4 & 48.5 & 57.1 & 57.3 & 86 & 60.1 \\
\hline Sr (ppm) & 423 & 479 & 449 & 411 & 264 & 78 \\
\hline$Y(p p m)$ & 1.2 & 1 & 1.8 & 7.3 & 5.9 & 1.3 \\
\hline $\mathrm{Zr}(\mathrm{ppm})$ & 60 & 63 & 64 & 178 & 203 & 6 \\
\hline $\mathrm{Nb}$ (ppm) & 0.7 & 0.6 & 1.9 & 3.9 & 4.7 & 1.2 \\
\hline Mo (ppm) & 0.21 & 0.12 & 0.24 & 0.17 & 0.19 & 1.4 \\
\hline $\mathrm{Ag}(\mathrm{ppm})$ & 0.08 & 0.02 & 0.04 & 0.02 & 0.04 & 0.05 \\
\hline Cd (ppm) & $<0.02$ & $<0.02$ & $<0.02$ & 0.03 & $<0.02$ & 0.13 \\
\hline In (ppm) & $<0.005$ & 0.005 & 0.005 & 0.017 & 0.015 & $<0.01$ \\
\hline Sn (ppm) & 0.3 & 0.2 & 0.4 & 0.8 & 1 & $<1$ \\
\hline Sb (ppm) & $<0.05$ & $<0.05$ & 0.05 & $<0.05$ & $<0.05$ & 0.08 \\
\hline Te (ppm) & $<0.05$ & $<0.05$ & $<0.05$ & $<0.05$ & $<0.05$ & $<0.2$ \\
\hline Cs (ppm) & 0.24 & 0.3 & 0.6 & 0.9 & 0.8 & 0.5 \\
\hline $\mathrm{Ba}(\mathrm{ppm})$ & 1390 & 1745 & 1050 & 258 & 1205 & 106.1 \\
\hline La (ppm) & 9.5 & 21.8 & 19.1 & 34.7 & 56.4 & 4 \\
\hline $\mathrm{Ce}$ (ppm) & 14.1 & 32.8 & 35.7 & 59.8 & 93.3 & 6.1 \\
\hline $\operatorname{Pr}(p p m)$ & 1.47 & 2.99 & 3.08 & 5.99 & 8.87 & 0.6 \\
\hline Nd (ppm) & 4.8 & 9.4 & 9.5 & 20 & 27.1 & 2.1 \\
\hline Sm (ppm) & 0.75 & 1.07 & 1.07 & 3.12 & 3.88 & 0.7 \\
\hline Eu (ppm) & 0.55 & 0.73 & 0.4 & 0.66 & 0.73 & 0.4 \\
\hline Gd (ppm) & 0.57 & 0.69 & 0.96 & 2.6 & 2.36 & 0.3 \\
\hline Tb (ppm) & 0.04 & 0.05 & 0.04 & 0.33 & 0.25 & $<0.1$ \\
\hline Dy (ppm) & 0.25 & 0.23 & 0.4 & 1.65 & 1.23 & 0.2 \\
\hline
\end{tabular}




\begin{tabular}{|c|c|c|c|c|c|c|}
\hline Ho (ppm) & 0.04 & 0.03 & 0.06 & 0.28 & 0.21 & $<0.1$ \\
\hline $\mathrm{Er}(p p m)$ & 0.15 & 0.08 & 0.12 & 0.65 & 0.44 & 0.1 \\
\hline Tm (ppm) & $<0.01$ & $<0.01$ & $<0.01$ & 0.08 & 0.11 & $<0.1$ \\
\hline $\mathrm{Yb}(\mathrm{ppm})$ & 0.12 & 0.07 & 0.1 & 0.61 & 0.47 & 0.1 \\
\hline Lu (ppm) & 0.02 & 0.01 & 0.01 & 0.09 & 0.07 & $<0.1$ \\
\hline Hf (ppm) & 1.8 & 1.8 & 1.7 & 4.4 & 5.3 & 0.2 \\
\hline Ta (ppm) & $<0.1$ & $<0.1$ & $<0.1$ & 0.1 & 0.1 & 0.4 \\
\hline W (ppm) & 0.1 & 0.1 & 0.1 & 0.1 & 0.1 & 2 \\
\hline $\operatorname{Re}(p p m)$ & $<0.002$ & $<0.002$ & $<0.002$ & $<0.002$ & $<0.002$ & $<0.002$ \\
\hline TI (ppm) & 0.29 & 0.28 & 0.3 & 0.39 & 0.56 & 0.31 \\
\hline $\mathrm{Pb}$ (ppm) & 22.5 & 22.2 & 21 & 16.3 & 20.8 & 23.8 \\
\hline $\mathrm{Bi}(\mathrm{ppm})$ & $<0.01$ & $<0.01$ & 0.01 & 0.01 & 0.01 & $<0.01$ \\
\hline Th (ppm) & 5.89 & 5.78 & 12.05 & 7.99 & 11.65 & 1.7 \\
\hline U (ppm) & 0.32 & 0.21 & 0.51 & 0.8 & 0.57 & 0.3 \\
\hline $\mathrm{K}_{2} \mathrm{O}+\mathrm{Na}_{2} \mathrm{O}$ & 7.52 & 7.44 & 7.69 & 6.82 & 7.40 & 7.52 \\
\hline $\mathrm{K}_{2} \mathrm{O} / \mathrm{Na}_{2} \mathrm{O}$ & 0.66 & 0.70 & 0.44 & 0.24 & 0.73 & 0.47 \\
\hline$(\mathrm{La} / \mathrm{Yb})_{\mathrm{cn}}$ & 44.2 & 208.0 & 144.2 & 36.2 & 64.1 & 28.7 \\
\hline$(\mathrm{La} / \mathrm{Sm})_{\mathrm{cn}}$ & 7.1 & 13.6 & 13.5 & 7.1 & 7.8 & 4.1 \\
\hline$\left(E u / E u^{*}\right)_{c n}$ & 2.6 & 2.6 & 1.2 & 0.71 & 0.74 & 2.67 \\
\hline M & 1.52 & 1.53 & 1.53 & 1.51 & 1.51 & 1.37 \\
\hline $\mathrm{T}_{\text {ZircSat }}$ & 600.4 & 560.5 & 643.2 & 688.0 & 681.7 & 491.1 \\
\hline $\mathrm{Zr} / \mathrm{Hf}$ & 33.3 & 35.0 & 37.6 & 40.5 & 38.3 & 30.0 \\
\hline Th/U & 18.4 & 27.5 & 23.6 & 10.0 & 20.4 & 5.7 \\
\hline
\end{tabular}

Olierook et al., Table 2 


\begin{tabular}{|c|c|c|c|c|c|}
\hline Property & Group 1 & Group 2 & Group 3 & Group 4 & Group 5 \\
\hline Samples & All & $872,1417,1416$ & $872,1417,1416$ & All except 1417 & 871,873 \\
\hline Lithologies & All & $\begin{array}{c}\text { Granodiorite, } \\
\text { Granite }\end{array}$ & $\begin{array}{c}\text { Granodiorite, } \\
\text { Granite }\end{array}$ & All & Trondhjemite \\
\hline Shape & Eu- to anhedral & Eu- to subhedral & Eu- to subhedral & An- to subhedral & An- to euhedral \\
\hline Size $(\mu \mathrm{m})$ & $80-200$ & $75-150$ & $120-150$ & $150-400$ & $200-300$ \\
\hline Aspect ratio & $1: 1-2: 1$ & $1: 1-4: 1$ & $1: 1-3: 1$ & $2: 1-4: 1$ & $2: 1-3: 1$ \\
\hline CL texture & $\begin{array}{l}\text { Homogeneous to faint } \\
\text { oscillatory or sector zoning }\end{array}$ & $\begin{array}{l}\text { Oscillatory } \\
\text { zoning }\end{array}$ & $\begin{array}{l}\text { Oscillatory and/or } \\
\text { sector zoning }\end{array}$ & $\begin{array}{l}\text { Mottling + weak } \\
\text { oscillatory zoning }\end{array}$ & $\begin{array}{l}\text { Highly mottled, choatic } \\
\text { to near-homogeneous }\end{array}$ \\
\hline Texture of rims & Oscillatory-zoned & $<15 \mu \mathrm{m}$, bright & $<25 \mu \mathrm{m}$, bright & Bright & $\mathrm{n} / \mathrm{a}$ \\
\hline \# concordant analyses & 34 & 29 & 14 & 31 & 17 \\
\hline Th/U range & $0.28-7.2$ & $0.80-2.4$ & $1.2-5.0$ & $0.03-2.1$ & $0.03-0.15$ \\
\hline Th/U median & 1.9 & 1.2 & 1.7 & 0.34 & 0.07 \\
\hline $\mathrm{U}$ range (ppm) & $66-385$ & $82-449$ & $27-82$ & $102-1538$ & $1275-3378$ \\
\hline U median (ppm) & 123 & 183 & 51 & 721 & 1777 \\
\hline TZircTi range $\left({ }^{\circ} \mathrm{C}\right)$ & $628-797$ & $605-925$ & $674-774$ & $616-865$ & $603-804$ \\
\hline $\mathrm{T}_{\text {ZircTi }}$ median $\left({ }^{\circ} \mathrm{C}\right)$ & 724 & 656 & 714 & 718 & 727 \\
\hline Date Range (Ma) & $3027-2986$ & $2991-2957$ & $3014-2959$ & $3066-3005$ & 3020-2832 \\
\hline Age $\pm 2 \sigma(M a)$ & $3010 \pm 4$ & $2974 \pm 4$ & $2982 \pm 10$ & $3039 \pm 5$ & $\mathrm{n} / \mathrm{a}$ \\
\hline
\end{tabular}

Olierook et al., Table 3 